\title{
Citrinin Mycotoxin Contamination in Food and Feed: Impact on Agriculture, Human Health, and Detection and Management Strategies
}

\author{
Madhu Kamle ${ }^{1}$ (D), Dipendra Kumar Mahato ${ }^{2}$ (D), Akansha Gupta ${ }^{3} \mathbb{D}$, Shikha Pandhi ${ }^{3}$, Nitya Sharma ${ }^{4}(\mathbb{D}$,

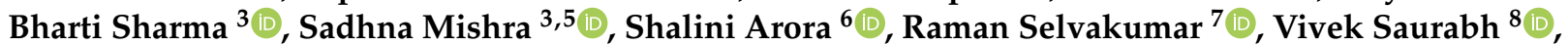 \\ Jyoti Dhakane-Lad ${ }^{9}$ (D), Manoj Kumar ${ }^{10}\left(\mathbb{D}\right.$, Sreejani Barua ${ }^{11,12}$, Arvind Kumar ${ }^{3}$, Shirani Gamlath ${ }^{2}$ (D) \\ and Pradeep Kumar 1,*iD
}

check for

updates

Citation: Kamle, M.; Mahato, D.K.; Gupta, A.; Pandhi, S.; Sharma, N.;

Sharma, B.; Mishra, S.; Arora, S.; Selvakumar, R.; Saurabh, V.; et al. Citrinin Mycotoxin Contamination in Food and Feed: Impact on Agriculture, Human Health, and Detection and Management Strategies. Toxins 2022, 14, 85. https://doi.org/10.3390/ toxins 14020085

Received: 5 November 2021 Accepted: 18 January 2022

Published: 23 January 2022

Publisher's Note: MDPI stays neutral with regard to jurisdictional claims in published maps and institutional affiliations.

Copyright: (C) 2022 by the authors. Licensee MDPI, Basel, Switzerland. This article is an open access article distributed under the terms and conditions of the Creative Commons Attribution (CC BY) license (https:// creativecommons.org/licenses/by/ $4.0 /)$.
1 Applied Microbiology Laboratory, Department of Forestry, North Eastern Regional Institute of Science and Technology, Nirjuli 791109, India; madhu.kamle18@gmail.com

2 CASS Food Research Centre, School of Exercise and Nutrition Sciences, Deakin University, Burwood 3125, Australia; kumar.dipendra2@gmail.com (D.K.M.); shirani.gamlath@deakin.edu.au (S.G.)

3 Department of Dairy Science and Food Technology, Institute of Agricultural Sciences, Banaras Hindu University, Varanasi 221005, India; salonigupta.ag@gmail.com (A.G.); shikhapandhi94@gmail.com (S.P.); sbharti51997@gmail.com (B.S.); sadhnamishra2649@gmail.com (S.M.); arvind00000@gmail.com (A.K.)

4 Food Customization Research Laboratory, Centre for Rural Development and Technology, Indian Institute of Technology Delhi, New Delhi 110016, India; nitya.sharma64@gmail.com

5 Faculty of Agricultural Sciences, GLA University, Mathura 281406, India

6 Department of Dairy Technology, College of Dairy Science and Technology, Lala Lajpat Rai University of Veterinary and Animal Sciences, Hisar 125004, India; shaliniarora.luvas@gmail.com

7 Centre for Protected Cultivation Technology, ICAR-Indian Agricultural Research Institute, Pusa Campus, New Delhi 110012, India; selvakumarsingai@gmail.com

8 Division of Food Science and Post-Harvest Technology, ICAR-Indian Agricultural Research Institute, New Delhi 110012, India; vivek.bhu12@gmail.com

9 Technology Transfer Division, ICAR-Central Institute for Research on Cotton Technology, Mumbai 400019, India; jyotip.dhakane@gmail.com

10 Chemical and Biochemical Processing Division, ICAR - Central Institute for Research on Cotton Technology, Mumbai 400019, India; manoj.kumar13@icar.gov.in

11 Department of Agricultural and Food Engineering, Indian Institute of Technology, Kharagpur 721302, India; sreejani301@iitkgp.ac.in

12 Max Planck Institute for Polymer Research, Ackermannweg 10, 55128 Mainz, Germany

* Correspondence: pkbiotech@gmail.com

\begin{abstract}
Citrinin (CIT) is a mycotoxin produced by different species of Aspergillus, Penicillium, and Monascus. CIT can contaminate a wide range of foods and feeds at any time during the pre-harvest, harvest, and post-harvest stages. CIT can be usually found in beans, fruits, fruit and vegetable juices, herbs and spices, and dairy products, as well as red mold rice. CIT exerts nephrotoxic and genotoxic effects in both humans and animals, thereby raising concerns regarding the consumption of CIT-contaminated food and feed. Hence, to minimize the risk of CIT contamination in food and feed, understanding the incidence of CIT occurrence, its sources, and biosynthetic pathways could assist in the effective implementation of detection and mitigation measures. Therefore, this review aims to shed light on sources of CIT, its prevalence in food and feed, biosynthetic pathways, and genes involved, with a major focus on detection and management strategies to ensure the safety and security of food and feed.
\end{abstract}

Keywords: citrinin; food and feed contamination; human health; detection and management strategies Key Contribution: Food and feed contamination with citrinin is a major concern worldwide. This article discusses its chemistry and biosynthesis, as well as its health consequences and impact on agricultural products, as well as detection and mitigation measures to assure the safety and security of food and feed. 


\section{Introduction}

Mycotoxins are poisonous secondary metabolites produced by filamentous fungi infesting crops and grain before harvest in the field or after harvest during storage [1]. Improper storage conditions regarding moisture, temperature, and water activity play a significant role in the proliferation of storage fungi and the production of toxins. Citrinin (CIT) is a polyketide-derived mycotoxin most commonly occurring during storage [2-4]. Hetherington and Raistrick isolated CIT for the first time from a culture of Penicillium citrinum in 1930s [5]. Meanwhile, it was reported that the three fungal genera Penicillium (P. citrinum, P. verrucosum, and P. expansum), Aspergillus (A. carneus, A. niveus, and A. terreus), and Monascus (M. ruber) could produce CIT [4-7]. Recently, CIT has also been found in food colorings traditionally made in Asia from rice fermented with Monascus purpureus ("red mold rice"), conventionally used for meat preservation and food coloring $[4,8]$.

Mycotoxins can contaminate the final food products and pose health concerns. However, recent advancements in food processing, such as hazard analysis of critical control points (HACCP) and good manufacturing practices (GMP), have aided in keeping final food products safe and healthy $[9,10]$. Apart from this, several degradation methods can be applied for the partial or complete elimination of these toxins from food to ensure consumer food safety and avoid health concerns. Though CIT has shown antibacterial [11], anticancer [12], and neuroprotective [13] properties, it is seldom used as a drug owing to its high nephrotoxicity and genotoxicity. Various in vitro and in vivo studies provided strong evidence of reproductive toxicity as well as the teratogenic and embryotoxic effects of CIT [4,14]. However, the International Agency for Research on Cancer (IARC) has classified CIT in Group III of carcinogens due to limited evidence in experimental animals and no evidence in humans regarding its carcinogenicity [4].

This review overviews the sources, chemistry, and biosynthesis of CIT, the effects of environmental factors on CIT production, its occurrence in food and feed, and the health effects in humans and animals. Moreover, the effects of processing techniques on CIT and various degradation methods with a major focus on detection and management strategies in food and feed are discussed.

\section{Major Source of Citrinin}

The fungi of the genera Penicillium, Aspergillus, and Monascus are major producers of CIT $[4,5]$. Penicillium spp. are of foremost importance and are reported to produce CIT worldwide during the drying and storage of cereal crops and other foodstuffs [14], among which Penicillium citrinum occurs most commonly in all kinds of food and feed, in almost all climatic conditions. Table 1 provides an overview of the current identity of microfungi Penicillium, Aspergillus, and Monascus species that can apparently produce CIT in foodstuffs $[4,6,7,15-17]$.

Table 1. Major citrinin producers among fungal species in foodstuffs.

\begin{tabular}{cccc}
\hline Genera & Subgenus & Series & Species \\
\hline Penicillium & Furcatum & - & P. citrinum Thom \\
& Penicillium & Expansa & P. expansum Link \\
& Penicillium & Corymbifera & P. radicicola Overy \& Frisvad \\
& Penicillium & Perrucosum Dierckx & P. viridicatum Westling \\
& Penicillium & Perrucosa camemberti Sopp & P. carneus Tiegh \\
& Penicillium & - & A. niveus Blochwitz \\
Aspergillus & - & - & A. oryzae \\
& - & - & A. terreus Thom \\
\hline Monascus & - & - & M. purpureus Went \\
& Circumdati & - & M. ruber Tiegh
\end{tabular}




\section{Chemistry and Biosynthesis of Citrinin}

CIT (Figure 1$)$ is a polyketide-containing mycotoxin $\left(\mathrm{C}_{13} \mathrm{H}_{14} \mathrm{O}_{5}\right.$, IUPAC: $(3 R, 4 S)-4,6-$ dihydro-8-hydroxy3,4,5-trimethyl-6-oxo-3H-2-benzopyran-7-carboxylic acid). It is a solid poison with the appearance of lemon-yellow needles at $\mathrm{pH}$ 4.6. The color changes to cherry red at $\mathrm{pH}$ 9.9. It melts at temperatures between 175 and $178.5^{\circ} \mathrm{C}$. In practice, it is insoluble in cold water but somewhat soluble in hot water, and it is soluble in aqueous sodium hydroxide, sodium carbonate, or sodium acetate, as well as in polar organic solvents such as ethanol, methanol, and acetonitrile. It has a UV-light absorption maximum ranging from 250 to $321 \mathrm{~nm}$ depending on the solvent [18]. CIT decomposes at temperatures exceeding $175{ }^{\circ} \mathrm{C}$ in dry conditions and over $100^{\circ} \mathrm{C}$ in wet ones [19]. CIT can be destroyed by acidic or alkaline liquids, as well as by heating. CIT is a quinone with two intramolecular hydrogen bonds [14].<smiles>CC1=C(O)C(C(=O)O)C(=O)C2=CO[C@H](C)C(C)C21</smiles>

Citrinin<smiles>CC1=C([C@H](C)[C@@H](C)OC=O)C(=O)C2=C(C1=O)C1O[C@H](C)[C@H](C)c3c(C)c(O)cc(c31)O2</smiles>

Citrinin $\mathrm{H} 1$<smiles>CC1=C(C(C)[C@@H](C)OC=O)CC(O)C=C1O</smiles>

Citrinin H2

Figure 1. Chemical structures of citrinin and its decomposition products citrinin $\mathrm{H} 1$ and citrinin $\mathrm{H} 2$.

CIT is synthesized via the polyketide pathway [20]. It is generally known that three secondary metabolites, pigments, monacolin $\mathrm{K}$, and citrinin, share a biochemical route before a specific branch step, which is generated by acetyl CoA and malonyl-CoA, particularly for pigment and citrinin. More research is needed to determine the impact of disrupting the biosynthetic pathway on the production of pigments and citrinin [21]. CIT biosynthesis in the genus Monascus appeared to be strain-specific. The compound biosynthesis appears to be a tetraketide rather than a pentaketide, as found in Aspergillus terreus and Penicillium citrinum. The tetraketide produced in Monascus is created by the condensation of one acetyl-CoA molecule with three malonyl-CoA molecules [22]. He and Cox [5] established the biosynthetic route of CIT in M. ruber M7 via target gene deletion and heterologous expression in Aspergillus oryzae, which involved the creation of an unreduced trimethyl pentaketide (thioester) by CitS, a non-reducing polyketide synthase (nrpks). The discovery of keto-aldehyde as the first enzyme-free intermediate with nrpks appears to be aided by a cryptic CitA-catalyzed hydrolysis step. CitB is a non-heme iron oxidase that catalyzes the conversion of methyl to alcohol. CitC catalyzed the conversion of alcohols to aldehydes, whereas CitD catalyzed the conversion of aldehydes to carboxylic acids. CitE catalyzed the end catalysis of C-3, resulting in CIT production (Figure 2) [5,23]. 


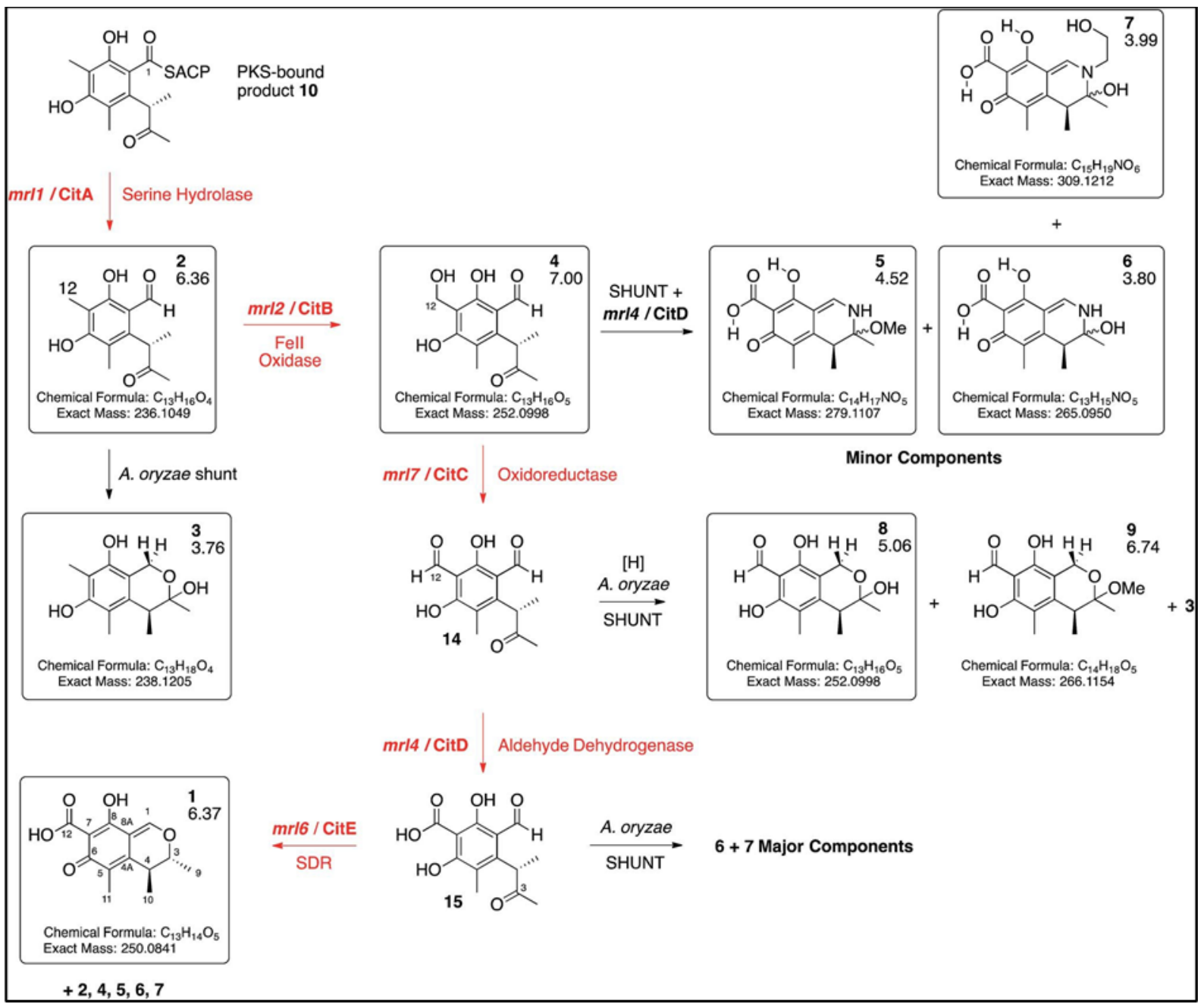

Figure 2. Schematic illustration of biosynthesis of CIT (adopted from He and Cox [5]).

\section{Genes Responsible for Citrinin Production}

Most polyketide metabolite pathway genes are grouped together. Six of the genes have comparable sequences to Monascus purpureus BCRC33325 citrinin biosynthesis pathway genes. PksCT, ctnA, orf1, orf3, orf4, and orf5 are all implicated. They successively encode a polyketide synthetase, a regulator, an aldehyde dehydrogenase, an oxygenase, an oxidoreductase, and a membrane transporter [20,24]. The capacity to generate citrinin was lost in the $p k s C T$ disruptant. The $p k s C T$ mutant was not genetically stable, and citrinin production was recovered following repeated culture [24]. Similarly, in Monascus aurantiacus, loss of $p k s C T$ resulted in a significant reduction in citrinin synthesis. Surprisingly, this mutant was able to generate more red and yellow pigments [25]. Furthermore, transcriptional regulation of fungal secondary metabolite pathways is tightly controlled. In M. purpureus, $\operatorname{ctn} A$ is a key transcriptional activator of citrinin production. The deletion of $\operatorname{ctn} A$ dramatically reduced the production of the $p k s C T$ transcript, which resulted in lower citrinin production [26,27]. The phenotype of citrinin production is lost when pksCT is disturbed. The $\operatorname{ctn} A$ gene encodes a $\mathrm{Zn}(\mathrm{II}) 2 \mathrm{Cys} 6$ binuclear DNA binding protein that is a significant inducer of citrinin synthesis. As a result, the $\operatorname{ctn} A$-deficient strain of $M$. purpureus produces so little CIT that it is barely detectable [22].

\section{Occurrence in Food and Feed}

CIT is found mainly in foodstuffs of vegetable origin. In addition, its presence is detected in various cereals (maize, wheat, rye, rice, corn, barley, oat) and cereal-based products, pomaceous fruits and fruit juices, roasted nuts (almonds, peanuts, hazelnuts, 
pistachio nuts), oilseeds (e.g., sunflower), and spices (e.g., turmeric, coriander, fennel, black pepper, cardamom and cumin) $[15,16,28,29]$. Cheese is also contaminated by CIT where toxigenic strains directly grow in the cheese mass [30]. CIT production is most likely when grains are not properly dried, retaining higher moisture content $(>16 \%)$. The favorable temperature range for growth of CIT is between 12 and $37^{\circ} \mathrm{C}$, with an optimum temperature at $30^{\circ} \mathrm{C}[1,4,17]$. Data on the occurrence of CIT in food and feed around the world are listed in Table 2.

Table 2. Occurrence of citrinin in food and feed around the world.

\begin{tabular}{|c|c|c|c|c|}
\hline Food Matrix & Country & Range ( $\mu \mathrm{g} / \mathrm{kg})$ & Detection Technique & References \\
\hline Amaranth & Spain & $1.8-5.9$ & QuEChERS & [31] \\
\hline Apples & $\begin{array}{l}\text { Portugal } \\
\text { Portugal } \\
\text { China } \\
\text { Croatia }\end{array}$ & $\begin{array}{c}320-920 \\
3.06-5.37 \\
1.7-16.3 \\
240\end{array}$ & $\begin{array}{c}\text { SPE-HPLC } \\
\text { TLC } \\
\text { UPLC-MS/MS } \\
\text { TLC }\end{array}$ & $\begin{array}{l}{[32]} \\
{[33]} \\
{[34]} \\
{[35]}\end{array}$ \\
\hline Almond & $\begin{array}{l}\text { Spain } \\
\text { India }\end{array}$ & $\begin{array}{c}3.0-7.4 \\
2.80-18.20\end{array}$ & $\begin{array}{c}\text { UHPLC-MS/MS } \\
\text { ELISA }\end{array}$ & $\begin{array}{l}{[36]} \\
{[37]}\end{array}$ \\
\hline $\begin{array}{c}\text { Barley } \\
\text { Black Pepper }\end{array}$ & $\begin{array}{l}\text { Czech Republic } \\
\text { India }\end{array}$ & $\begin{array}{l}93.64 \\
17.8\end{array}$ & $\begin{array}{c}\text { HPLC } \\
\text { LC-MS/MS }\end{array}$ & $\begin{array}{l}{[38]} \\
{[16]}\end{array}$ \\
\hline Black olives & $\begin{array}{l}\text { Turkey } \\
\text { Morocco }\end{array}$ & $\begin{array}{c}350 \\
0.2-0.5\end{array}$ & $\begin{array}{l}\text { TLC } \\
\text { HPLC }\end{array}$ & $\begin{array}{l}{[39]} \\
{[40]}\end{array}$ \\
\hline Breakfast cereals & $\begin{array}{l}\text { France } \\
\text { France }\end{array}$ & $\begin{array}{l}1.5-42 \\
0.5-1.5 \\
\end{array}$ & $\begin{array}{l}\text { HPLC-FD } \\
\text { HPLC }\end{array}$ & $\begin{array}{l}{[41]} \\
{[42]} \\
\end{array}$ \\
\hline Brown rice & Spain & $6.4-10$ & QuEChERS & [31] \\
\hline Buckwheat & $\begin{array}{l}\text { Spain } \\
\text { Spain }\end{array}$ & $\begin{array}{c}1.5-6.9 \\
0.62\end{array}$ & $\begin{array}{l}\text { QuEChERS } \\
\text { LC-MS/MS }\end{array}$ & $\begin{array}{l}{[31]} \\
{[43]}\end{array}$ \\
\hline $\begin{array}{c}\text { Cashew } \\
\text { Cajna salami }\end{array}$ & $\begin{array}{c}\text { India } \\
\text { Croatia }\end{array}$ & $\begin{array}{l}4.70-9.80 \\
<1.0-1.0 \\
\end{array}$ & $\begin{array}{l}\text { ELISA } \\
\text { HPLC }\end{array}$ & $\begin{array}{l}{[37]} \\
{[44]} \\
\end{array}$ \\
\hline Cereals & $\begin{array}{l}\text { Belgium } \\
\text { Croatia }\end{array}$ & $\begin{array}{c}14.3 \\
19.63 \\
\end{array}$ & $\begin{array}{c}\text { UHPLC-MS/MS } \\
\text { HPLC-FD }\end{array}$ & {$[45]$} \\
\hline $\begin{array}{c}\text { Cereal solid substrates } \\
\text { Cereals and derivatives } \\
\text { Cocoa } \\
\text { Coriander } \\
\text { Commercial beers } \\
\text { Cumin } \\
\text { Dried grape } \\
\text { Dried white mulberry } \\
\text { Dry ginger } \\
\text { Family Cereal } \\
\text { Fermented dry meat products } \\
\text { Fenugreek } \\
\text { Fruits } \\
\text { Grape } \\
\text { Ground rice } \\
\text { Hazelnut } \\
\text { Industrially-processed complementary foods } \\
\text { Infant formula } \\
\text { Koji rice } \\
\text { Lager beer } \\
\text { Liquorice root } \\
\text { Monascus pigment powder }\end{array}$ & $\begin{array}{l}\text { Poland } \\
\text { Germany } \\
\text { Belgium } \\
\text { India } \\
\text { South Africa } \\
\text { India } \\
\text { Turkey } \\
\text { Turkey } \\
\text { India } \\
\text { Nigeria } \\
\text { Croatia } \\
\text { India } \\
\text { China } \\
\text { China } \\
\text { China } \\
\text { Spain } \\
\text { Nigeria } \\
\text { Nigeria } \\
\text { USA } \\
\text { Czech Republic } \\
\text { Turkey } \\
\text { China }\end{array}$ & $\begin{array}{c}5.7-74.8 \\
<1-2.7 \\
3.4 \\
23.0 \\
6 \\
14.7 \\
5.56 \\
4.26-5.29 \\
19.4 \\
1.2-151 \\
<1.0-1.3 \\
17.2 \\
0.06-0.10 \\
0.16 \\
5-100 \\
3.1-8.0 \\
1.2-151 \\
3.6 \\
50-1000 \\
0.2-10 \\
14.66-19.14 \\
122-594\end{array}$ & $\begin{array}{c}\text { HPLC-FLD } \\
\text { HPLC-FD } \\
\text { UHPLC-MS/MS } \\
\text { LC-MS/MS } \\
\text { TLC } \\
\text { LC-MS/MS } \\
\text { HPLC-FD } \\
\text { HPLC-FD } \\
\text { LC-MS/MS } \\
\text { LC-MS/MS } \\
\text { ELISA } \\
\text { LC-MS/MS } \\
\text { QuEChERS-HPLC-FLD } \\
\text { USAE-DLLME-HPLC-FLD } \\
\text { HPLC-DAD } \\
\text { UHPLC-MS/MS } \\
\text { LC-MS/MS } \\
\text { LC-MS/MS } \\
\text { IAC-HPLC } \\
\text { SPE-HPLC } \\
\text { HPLC-FD } \\
\text { RP-HPLC }\end{array}$ & $\begin{array}{l}46] \\
{[41]} \\
{[45]} \\
{[16]} \\
{[47]} \\
{[16]} \\
{[48]} \\
{[48]} \\
{[16]} \\
{[49]} \\
{[44]} \\
{[16]} \\
{[50]} \\
{[50]} \\
{[51]} \\
{[36]} \\
{[49]} \\
{[49]} \\
{[52]} \\
{[32]} \\
{[48]} \\
{[53]}\end{array}$ \\
\hline Maize & $\begin{array}{c}\text { Serbia } \\
\text { China } \\
\text { Mozambique/Burkina } \\
\text { Faso }\end{array}$ & $\begin{array}{c}5-547 \\
4.71-18.49 \\
531-5074\end{array}$ & $\begin{array}{l}\text { LC-MS/MS } \\
\text { ic-ELISA } \\
\text { LC-MS/MS }\end{array}$ & $\begin{array}{l}{[54]} \\
{[55]} \\
{[56]}\end{array}$ \\
\hline $\begin{array}{c}\text { Macadamia nut } \\
\text { Medicinal and aromatic herbs } \\
\text { Mushroom } \\
\text { Ogi } \\
\text { Olive } \\
\text { Orange } \\
\text { Parboiled rice } \\
\text { Pear } \\
\text { Peanut } \\
\text { Pine nuts } \\
\text { Pumpkin seed }\end{array}$ & $\begin{array}{l}\text { Spain } \\
\text { Spain } \\
\text { USA } \\
\text { Nigeria } \\
\text { China } \\
\text { China } \\
\text { India } \\
\text { China } \\
\text { Spain } \\
\text { Spain } \\
\text { Spain }\end{array}$ & $\begin{array}{c}3.3-7.3 \\
16.5 \\
400 \\
0.8-159 \\
0.05 \\
40.3 \\
12-55 \\
0.16 \\
2.9-8.9 \\
5.5-9.0 \\
2.6-7.3\end{array}$ & $\begin{array}{c}\text { UHPLC-MS/MS } \\
\text { ELISA } \\
\text { IAC-HPLC } \\
\text { LC-MS/MS } \\
\text { IAC-HPLC-FLD } \\
\text { UPLC-MS/MS } \\
\text { HPLC } \\
\text { USAE-DLLME-HPLC-FLD } \\
\text { UHPLC-MS/MS } \\
\text { UHPLC-MS/MS } \\
\text { UHPLC-MS/MS }\end{array}$ & $\begin{array}{l}{[36]} \\
{[57]} \\
{[52]} \\
{[49]} \\
{[50]} \\
{[34]} \\
{[58]} \\
{[50]} \\
{[36]} \\
{[36]} \\
{[36]}\end{array}$ \\
\hline
\end{tabular}


Table 2. Cont.

\begin{tabular}{|c|c|c|c|c|}
\hline Food Matrix & Country & Range ( $\mu \mathrm{g} / \mathrm{kg})$ & Detection Technique & References \\
\hline Pistachio & $\begin{array}{l}\text { Spain } \\
\text { India }\end{array}$ & $\begin{array}{c}4.4-8.5 \\
4.57-15.80\end{array}$ & $\begin{array}{l}\text { UHPLC-MS/MS } \\
\text { ELISA }\end{array}$ & $\begin{array}{l}{[36]} \\
{[37]}\end{array}$ \\
\hline $\begin{array}{l}\text { Quinoa } \\
\text { Raisin } \\
\text { Red chilli }\end{array}$ & $\begin{array}{l}\text { Spain } \\
\text { India } \\
\text { India }\end{array}$ & $\begin{array}{c}5.3-6.9 \\
2.84-17.40 \\
12.5\end{array}$ & $\begin{array}{l}\text { QuEChERS } \\
\text { ELISA } \\
\text { LC-MS/MS }\end{array}$ & $\begin{array}{l}{[31]} \\
{[37]} \\
{[16]}\end{array}$ \\
\hline Red rice & $\begin{array}{c}\text { Spain } \\
\text { Malaysia }\end{array}$ & $\begin{array}{c}2.8-6.2 \\
0.23-20.65\end{array}$ & $\begin{array}{c}\text { QuEChERS } \\
\text { ELISA }\end{array}$ & $\begin{array}{l}{[31]} \\
{[59]}\end{array}$ \\
\hline Red kojic rice & $\begin{array}{l}\text { China } \\
\text { Japan } \\
\text { China }\end{array}$ & $\begin{array}{r}50 \\
200 \\
100\end{array}$ & $\begin{array}{l}\text { HPLC-FD } \\
\text { MFEI } \\
\text { IAC }\end{array}$ & $\begin{array}{l}{[60]} \\
{[61]} \\
{[62]}\end{array}$ \\
\hline Red mold rice & $\begin{array}{l}\text { USA } \\
\text { Malaysia } \\
\text { USA } \\
\text { Taiwan } \\
\text { China } \\
\text { China }\end{array}$ & $\begin{array}{c}50-2500 \\
0.23-20.65 \\
24-189 \\
5742-27,000 \\
49-13,550 \\
7.5-120\end{array}$ & $\begin{array}{l}\text { IAC-HPLC } \\
\text { HPLC } \\
\text { HPLC-UV } \\
\text { HPLC-FLD } \\
\text { HPLC-FLD } \\
\text { HPLC }\end{array}$ & $\begin{array}{l}{[52]} \\
{[59]} \\
{[63]} \\
{[64]} \\
{[64]} \\
{[64]}\end{array}$ \\
\hline Red fermented rice & $\begin{array}{l}\text { China } \\
\text { China } \\
\text { Croatia } \\
\text { China } \\
\text { China }\end{array}$ & $\begin{array}{c}140-44,240 \\
0.12-5.71 \\
95-98 \\
0.14-44.24 \\
250-825\end{array}$ & $\begin{array}{c}\text { LC-MS/MS } \\
\text { HPLC } \\
\text { Rapid LC/DAD/FLD/MS } \\
\text { LC-MS/MS } \\
\text { HPLC-FLD }\end{array}$ & $\begin{array}{l}{[65]} \\
{[66]} \\
{[67]} \\
{[65]} \\
{[65]}\end{array}$ \\
\hline Red yeast rice & $\begin{array}{l}\text { China } \\
\text { Belgium } \\
\text { China } \\
\text { China } \\
\text { China } \\
\text { Croatia }\end{array}$ & $\begin{array}{c}2.33-32.47 \\
3.6-121,097 \\
57.28 \\
100.6-443.6 \\
16.6-5253 \\
98\end{array}$ & $\begin{array}{c}\text { MFCI } \\
\text { UHPLC-MS/MS } \\
\text { HPLC-FLD } \\
\text { IAC-HPLC } \\
\text { LC-MS/MS } \\
\text { LC-MS }\end{array}$ & $\begin{array}{l}{[68]} \\
{[45]} \\
{[69]} \\
{[70]} \\
{[68]} \\
{[71]}\end{array}$ \\
\hline $\begin{array}{c}\text { Red yeast rice powder } \\
\text { Red yeast powder } \\
\text { Red yeast rice food additives } \\
\text { Red yeast rice functional food and medicine products }\end{array}$ & $\begin{array}{l}\text { China } \\
\text { China } \\
\text { China } \\
\text { China }\end{array}$ & $\begin{array}{c}0.10-5.41 \\
55 \\
127-4960 \\
16.6-62.5\end{array}$ & $\begin{array}{l}\text { RP-HPLC } \\
\text { HPLC-FD } \\
\text { LC-MS/MS } \\
\text { LC-MS/MS }\end{array}$ & $\begin{array}{l}{[53]} \\
{[62]} \\
{[68]} \\
{[68]}\end{array}$ \\
\hline Rice & $\begin{array}{c}\text { Argentina } \\
\text { Vietnam } \\
\text { Iran } \\
\text { Vietnam } \\
\text { China } \\
\text { China } \\
\text { Spain } \\
\text { Japan } \\
\text { Canada } \\
\text { China } \\
\text { Iran } \\
\text { India }\end{array}$ & $\begin{array}{c}0.5-50 \\
0.42 \\
5-21.05 \\
0.38-0.42 \\
0.11 \\
0.7-1.0 \\
5-200 \\
49-92 \\
700-1130 \\
9.65-19.85 \\
5-21.05 \\
49-92\end{array}$ & $\begin{array}{c}\text { ELISA } \\
\text { HPLC-FLD } \\
\text { LC-MS/MS } \\
\text { UHPLC-FL } \\
\text { LLE-HPLC-FLD } \\
\text { SPME-LC-FLD } \\
\text { HPLC-DAD } \\
\text { HPLC } \\
\text { HPLC } \\
\text { ic-ELISA } \\
\text { HPLC } \\
\text { HPLC }\end{array}$ & $\begin{array}{l}{[61]} \\
{[72]} \\
{[73]} \\
{[74]} \\
{[50]} \\
{[50]} \\
{[75]} \\
{[76]} \\
{[76]} \\
{[55]} \\
{[58]} \\
{[58]}\end{array}$ \\
\hline Sausages & Croatia & $<1.0-1.0$ & ELISA & {$[44]$} \\
\hline Semi-dry sausages & $\begin{array}{l}\text { Croatia } \\
\text { Croatia }\end{array}$ & $\begin{array}{l}<1.0 \\
<1.0\end{array}$ & $\begin{array}{l}\text { HPLC } \\
\text { ELISA }\end{array}$ & $\begin{array}{l}44] \\
{[44]}\end{array}$ \\
\hline $\begin{array}{c}\text { Spices } \\
\text { Spelt } \\
\text { Soybean } \\
\text { Sunflower seed } \\
\text { Sweet cherries } \\
\text { Tomato } \\
\text { Tom bran } \\
\text { Tom bran } \\
\text { Walnut } \\
\text { White rice }\end{array}$ & $\begin{array}{l}\text { Belgium } \\
\text { Spain } \\
\text { Egypt } \\
\text { Spain } \\
\text { China } \\
\text { China } \\
\text { Nigeria } \\
\text { Nigeria } \\
\text { Spain } \\
\text { Spain }\end{array}$ & $\begin{array}{c}1.4-19.8 \\
2.6-10.4 \\
270 \\
4.6-10.2 \\
2.2-7.9 \\
1.1-8.4 \\
1.7-1173 \\
0.8-1173 \\
4.6-7.7 \\
4.0-6.4\end{array}$ & $\begin{array}{c}\text { UHPLC-MS/MS } \\
\text { QuEChERS } \\
\text { HPLC } \\
\text { UHPLC-MS/MS } \\
\text { UPLC-MS/MS } \\
\text { UPLC-MS/MS } \\
\text { LC-MS/MS } \\
\text { LC-MS/MS } \\
\text { UHPLC-MS/MS } \\
\text { UHPLC-MS/MS }\end{array}$ & $\begin{array}{l}{[45]} \\
{[31]} \\
{[77]} \\
{[36]} \\
{[34]} \\
{[34]} \\
{[49]} \\
{[49]} \\
{[36]} \\
{[31]}\end{array}$ \\
\hline Wheat & $\begin{array}{l}\text { Tunisia } \\
\text { Canada } \\
\text { China } \\
\text { Czech Republic }\end{array}$ & $\begin{array}{l}0.1-170 \\
175.2 \\
4.77-19.49 \\
0.09\end{array}$ & $\begin{array}{l}\text { HPLC } \\
\text { HPLC } \\
\text { ic-ELISA } \\
\text { HPLC-FD }\end{array}$ & $\begin{array}{l}{[78]} \\
{[79]} \\
{[55]} \\
{[80]}\end{array}$ \\
\hline Wheat flour & $\begin{array}{c}\text { Belgium } \\
\text { Czech Republic }\end{array}$ & $\begin{array}{c}0.1 \\
19.2-2068.6\end{array}$ & $\begin{array}{l}\text { UHPLC-MS/MS } \\
\text { HPLC-FD }\end{array}$ & $\begin{array}{l}{[45]} \\
{[80]}\end{array}$ \\
\hline Winter salami & Croatia & $<1.0-1.3$ & HPLC & {$[44]$} \\
\hline Feed & & & & \\
\hline
\end{tabular}


Table 2. Cont.

\begin{tabular}{|c|c|c|c|c|}
\hline Food Matrix & Country & Range ( $\mu \mathrm{g} / \mathrm{kg})$ & Detection Technique & References \\
\hline Feed & Burkina Faso & 341 & LC-MS/MS & {$[56]$} \\
\hline Complete animal feeds & Belgium & $1.9-2.0$ & UHPLC-MS/MS & {$[45]$} \\
\hline Maize silage & France & $1.5-5.0$ & LC-MS & [81] \\
\hline Maize silage & France & $5-25$ & LC-MS & {$[82]$} \\
\hline Maize silage & France & $2-1.5$ & LC-MS & {$[83]$} \\
\hline Compounded feeds & Russia & $10-182$ & ELISA & {$[84]$} \\
\hline Maize gluten & Russia & 62 & ELISA & {$[84]$} \\
\hline Wheat bran & Russia & 397 & ELISA & {$[84]$} \\
\hline Soy-bean oilseed meal & Russia & 30 & ELISA & {$[84]$} \\
\hline
\end{tabular}

UHPLC-MS/MS: Ultra-high-performance liquid chromatography tandem mass spectrometry; UHPLC-FL: Ultrahigh-performance liquid chromatography and fluorescence detection; LLE-HPLC-FD: Liquid-liquid extractionhigh performance liquid chromatography-fluorescence detector; IAC-HPLC-FD: Immunoaffinity column-high performance liquid chromatography-fluorescence detector; SPE-HPLC-FD: Solid phase microextraction-high performance liquid chromatography-fluorescence detector; QuEChERS: quick, easy cheap, effective, rugged, and safe high performance liquid chromatography-fluorescence detector; USAE-DLLME-HPLC-FLD: ultrasound solvent extraction-dispersive liquid-liquid microextraction-high performance liquid chromatography-fluorescence detector; SPE-HPLC: Solid-phase extraction-high performance liquid chromatography; MFEI: micro fluidic electrochemical immunosensor; icELISA: indirect competitive enzyme-linked immunosorbent assay; UHPLCMS/MS: Ultra-high performance liquid chromatography coupled with tandem mass spectrometry: RP-HPLC: Reversed-phase HPLC; MFCI: microsphere-based flow cytometric immunoassay; IAC: Immunoaffinity columns; USAE-DLLME: ultrasound-assisted extraction combined with dispersive liquid-liquid microextraction.

\section{Effects on Agricultural Food and Feed}

Agricultural products can be contaminated during pre-harvest, harvest, and postharvest conditions. CIT contaminates harvested grains, dairy products, spices, juices from fruits and vegetables, herbs, and citrus fruits [23]. Wang et al. [85] observed the significant presence of toxigenic strains of CIT in cheese. According to the EFSA [28], CIT is mostly found in a few agricultural products, fruits, biological fluids, animal feed, and dairy products. Irradiation (ultraviolet, UV) of fruits containing $280-400 \mu \mathrm{g} / \mathrm{kg}$ of CIT resulted in destruction, with no presence of CIT found in the fruits. Following the report by the EFSA [28], CIT can be associated with ochratoxin A and aflatoxin B in grain products and cereals as well as with patulin in the case of apple juices and apple jams [28]. CIT production is also regulated by nutritive elements such as oxygen availability, fatty acids, nitrogen, and carbon sources, besides environmental factors such as water activity, temperature, commodity preservation, and storage conditions [85]. There is a regular occurrence of CIT in food and feed with the potential chance of consumer exposure to the toxin; still, no legal limits have been set [86]. However, the European Commission declared the presence of a maximum safe limit of up to $100 \mu \mathrm{g} / \mathrm{kg}$ in food supplements [87]. CIT in fermented red rice has a maximum limit of $50 \mu \mathrm{g} / \mathrm{kg}$ in China and $200 \mu \mathrm{g} / \mathrm{kg}$ in Japan [75]. In addition, the European Union in 2014 has set a maximum limit of $2000 \mu \mathrm{g} / \mathrm{kg}$ in rice fermented with red yeast $M$. purpureus [88].

\section{Mechanism of Toxicity and Health Effects of Citrinin}

\subsection{Mechanism of Toxicity}

The two basic mechanisms of CIT-mediated harmful effects in biological systems are assumed to be the effects of oxidative stress and altered enzymatic antioxidative responses (e.g., epithelial glutathione and transhydrogenase) [14]. In the respiratory chain, CIT has been discovered to promote the creation of reactive oxygen species (ROS) and boost the synthesis of superoxide anions. These bioactivities could explain lipid peroxidation [89] and cell death associated with mitochondrial malfunction [90]. The activation of caspases-3, $-6,-7$, and -9 has been linked to CIT triggered apoptosis in kidney PK15 cells and human promyelocytic leukemia (HL-60) cells [91]. CIT (108, 324, and 970 ppm) has been shown in several studies to cause harmful consequences in varieties of yeast cells by inducing oxidative stress and upregulating genes from oxidative stress response such as AADs, OYE3, FLR1, GRE2, and MET17 [92,93].

CIT has previously been shown to accumulate in the budding yeast mitochondria, and exposure with CIT causes malfunction of respiratory system as well as mitochondrial complex I inhibition [94]. Dysfunction in mitochondria caused by suppression of mitochondrial 
complex I resulted in superoxide anion $\left(\mathrm{O}_{2}{ }^{-}\right)$production. Similarly, exposure with CIT for 60 min increased the amount of ROS in hepatocarcinoma HepG2 cells (10-30 $\mu \mathrm{M})$ [95]. As a result, it seems that CIT-induced ROS generation is required for initiation in apoptosis and that antioxidant system activation and adaptive responses mediated through ROS-sensitive transcription factors are activated. CIT treatment $(1000 \mu \mathrm{M})$ of cells $\left(107 \mathrm{~mL}^{-1}\right)$ for $60 \mathrm{~min}$ at $\mathrm{pH} 4.5$ resulted in a considerable rise in peroxides and total ROS as well as a 3-fold increase in glutathione concentration, with no change in superoxide or hydroxyl radical levels [96]. CIT treatment raised ROS levels in hepatocarcinoma HepG2 cells (10-30 $\mu \mathrm{M})$ for $60 \mathrm{~min}$ [95] and in single cells from the murine skin suspensions at 50 $\mu \mathrm{M}$ for 12-72 $\mathrm{h}$ [97]. This suggests that CIT-induced ROS generation is required for apoptosis and antioxidant system activation, as well as for adaptive responses, which are mediated through the activation of ROS-sensitive transcription factors. A decrease in GSH due to conjugation with patulin as well as molecular interactions of CIT with the free sulfhydryl groups of integrative membrane proteins lead to cell death [96]. CIT may affect the plasma membrane by inhibiting 3-hydroxy-3-methylglutaryl-coenzyme in a time-dependent, irreversible manner. Long-term exposure to a reductase disrupts the synthesis of the cholesterol/ testosterone (and ergosterol) pathway, resulting in hypocholesterolemia [98]. In acute testing, CIT inhibited growth, cell proliferation, viability, cytotoxicity, and many other measured parameters in a dose- and time-dependent manner, regardless of the kind of cells used [96]. In chronic tests, CIT I inhibited one of the key enzymes involved in cholesterol synthesis (resulting in lower serum testosterone levels and hypocholesterolemia) [99], had multiple immune modulator effects [100], and caused nephropathy, hepato- and fetotoxicity, and renal adenoma formation in various animal models [101].

\subsection{Health Effects of Citrinin}

CIT has been shown to be nephrotoxic and hepatotoxic to humans. The kidney is the major target organ of CIT [9]. CIT is commonly found along with ochratoxin, and an additive or synergic effect has been shown to increase the toxicity, causing kidney disease in humans [102,103]. Other than the kidney, the target organs of CIT include the liver, mitochondrial respiratory chain, and bone marrow [14]. This nephrotoxin is also considered as one possible reason for porcine nephropathy. In the absence of adequate exposure data, the risk of CIT as a food contaminant was assessed based on an estimate of the critical CIT concentrations in grains and grain-based products that would result in nephrotoxicity [28]. Furthermore, CIT is quickly absorbed and transported, particularly to the liver and kidney. A recent human CIT toxic kinetic study revealed that $40 \%$ of CIT was eliminated in the urine, implying that $40 \%$ of CIT was absorbed [17]. In a study by López Sáncheza, et al. [104], CIT in European foodstuffs was identified, where red yeast rice (RYR) samples $(n=92)$ were reported to be highly susceptible to CIT contamination. The findings of this study demonstrate the uncertainty regarding the carcinogenicity and genotoxicity of CIT, leading to a reconsideration of selection of the optimum level to protect public health and particularly consumers of RYR supplements [87].

Furthermore, CIT, when examined at 20 and $50 \mu \mathrm{g}$ in embryos of Zebrafish, reduced blood flow rate and heartbeat, probably through modulating the expression of the jun $B$ and tbx2a genes. Male and female mice subjected to CIT therapy at $0.065 \mathrm{mg} / 100 \mathrm{~g}$ (p.o.) for 60 days showed morphological changes as well as a noteworthy reduction in weight in the body and organs. Hemosiderin granules were found in some of the organs as well. Male infertility was discovered, as well as changes in parameters of hematology [105]. In mouse blastocysts, CIT at 15 or $30 \mu \mathrm{M}$ has been shown to enhance apoptotic events and decrease overall cell counts. CIT $(2.5$ and $5.0 \mu \mathrm{M})$ has also been observed to impair the maturation rate of the oocyte, as well as fertilization and embryo development in ICR mice [106]. In Kunming strain male mice $(n=6)$, CIT at $0-6.25 \mathrm{mg} / \mathrm{kg}$ body wt./d (i.p.) for 7 days resulted in various substantial alterations which included an increase in the epididymis, the relative weights of the testes, preputial glands, and seminal vesicles, and the quantity of aberrant spermatozoa. Furthermore, when CIT-exposed males were mated 
with females, the pregnancy rate was shown to be lower, implying a negative influence on the reproductive system. In research conducted with $40 \mathrm{mg} / \mathrm{kg}$ body wt./ $\mathrm{d}$ CIT (gastric intubation) in 14-day-old male and female guinea pigs ( $n=5$ to 15), Thacker et al. [107] observed several alterations including dehydration, loss of body weight, liver and kidney damage (primarily degeneration and necrosis), and anemia. Jordan et al. [108] found that CIT at 62 and $87 \mathrm{mg} / \mathrm{kg}$ body wt. (p.o.) caused kidney lesions in female mice ( $n=5$ to 15), with renal tubular dilatation and deposition of protein within the lumen of the renal tubules. Furthermore, in rabbits $(n=6)$, Hanika et al. [109] observed that CIT (33.5 or $77 \mathrm{mg} / \mathrm{kg}$ body wt./d administered for 7 days) caused renal changes including minor tubular regeneration and necrosis, as well as tubular degeneration. Jordan et al. [110] reported that only one intraperitoneal (i.p.) dose of CIT (50 mg/ kg body wt.) could cause nephrosis in Sprague-Dawley rats, based on increased blood and glucose in urine within the initial 3 hours. CIT administered at a dosage of $120 \mathrm{mg} / \mathrm{kg}$ body wt. (p.o.) caused metabolic acidosis and azotaemia as well as hypokalemia and hemoconcentration within 4-12 h in male New Zealand white rabbits [111].

\section{Effects of Processing on Citrinin}

The toxigenic potential of the fungi and thereby the yield of toxins can be affected by conditions during harvest, storage, and processing operations. CIT levels decreased in the products after processing due to its sensitivity to heat. CIT is decomposed into two other complexes, namely CIT-H1 and CIT-H2, after the heat treatment generally above $175{ }^{\circ} \mathrm{C}$ under dry conditions and above $100{ }^{\circ} \mathrm{C}$ in the presence of water [101,112]. CIT$\mathrm{H} 2$ has lower toxicity than CIT, while CIT-H1 is more toxic [101,113]. Dicitrinin A is another decomposition product of CIT reported recently together with other degradation products $[17,28,114]$. Besides temperature, the addition of compounds such as flavonoids can also affect the level of CIT. Wang et al. [115] investigated the effect of isoflavone and genistein on CIT production by Monascus aurantiacus Li AS3.4384 (MAL) during liquidstate fermentation containing rice powder as a carbon source and $2.0 \mathrm{~g} / \mathrm{L}$ genistein. The results showed a significant reduction in CIT levels (approximately $80 \%$ ) and an increase in biomass. Other flavonoids such as quercetin, kaempferol, myricetin, and genistin were also tested for their effectiveness; however, the maximum reduction was observed in the case of genistein. Further research by Ouyang et al. [116] showed that the reduction was due to changes occurring at the transcription level. When transcriptome analysis of groups treated with genistein and control was performed, several genes that were significantly downregulated with genistein addition, thereby demonstrating their involvement in CIT production. A similar study by Huang et al. [117] investigated the effect of the addition of rutin and its derivatives, $\alpha$-glucosylrutin and troxerutin, in fermentation media on Monascus aurantiacus Li AS3.4384 CIT production. The results showed that inhibition by rutin derivatives was significantly higher (>50\%) than rutin (around 20\%) when added at the same concentration. In addition, the media composition also affected the reduction in CIT yield. The highest reduction of about $90 \%$ was observed after 14 days of fermentation when $15.0 \mathrm{~g} / \mathrm{L}$ of troxerutin was added to low-starch peptone containing liquid media [117].

In addition, several novel technologies have been incorporated in the food industry, such as high hydrostatic pressure (HHP), ultrasonication, and cold atmospheric pressure plasma (CAPP). Application of HHP on the infected olives successfully reduced the microbial population by $90-100 \%$ and degraded CIT up to $100 \%$. Moreover, HHP also enhanced phenolic compounds and antioxidant activity [118]. The addition of $6-9 \% \mathrm{NaCl}$ significantly reduced CIT production during olive storage [119]. Similarly, ultrasonication of red yeast rice degraded up to $87.7 \%$ of CIT produced by Monascus purpureus during fermentation [120]. On the other hand, CAPP degraded up to 50\% of CIT developed by Penicillium sp. collected from wheat, oat, corn, and rice, without affecting the nutritional quality of grains [121]. 


\section{Effects of Environmental Factors on Citrinin Production}

Environmental factors such as temperature, $\mathrm{pH}$, and light (especially during storage) affect the growth of fungus and the production of mycotoxin. Regulation of such environmental conditions, therefore, would help control the growth of fungus and thereby the release of toxins [122-124]. Wawrzyniak and Waśkiewicz [46] investigated the effect of temperature $\left(10,20\right.$, and $30^{\circ} \mathrm{C}$ ) and different cereal substrates (wheat, triticale, rye, barley, maize, rice) on the growth of $P$. verrucosum and the production of CIT while maintaining the moisture content. For the experiment, the cereals were moistened, autoclaved, and then inoculated with the fungal spores. The inoculated cereals were then kept under different storage temperatures for 40 days. To determine growth, ergosterol (ERG) was used as a biomarker and the mycotoxin content was determined using HPLC. The results showed maximum ERG at $30^{\circ} \mathrm{C}$, although growth was observed at all temperatures. Mycotoxin (CIT) was observed to be accumulated more at $20^{\circ} \mathrm{C}$ in rice. The study suggested that irrespective of the temperature and cereal substrate, there is no strong correlation between the production of ERG and mycotoxin. This is reflected by the experiment since the optimal conditions for growth $\left(30^{\circ} \mathrm{C}\right)$ and CIT production $\left(20^{\circ} \mathrm{C}\right)$ do not coincide.

Another study by Yang et al. [125] investigated the effect of blue light on the yield of CIT. It was found that exposure to blue light for $15 \mathrm{~min}$ per day can significantly increase the toxin's production in Monascus purpureus, and a decrease was observed when the exposure time was raised to $60 \mathrm{~min} / \mathrm{d}$. The addition of aminophylline and citric acid to the culture medium under illuminating conditions increased the expression of the mraox gene while decreasing the expression of lncRNA AOANCR, ultimately leading to a reduction in the production of CIT [125]. Furthermore, the effects of intensity of light and its color were investigated to determine the effect on biomass, pigment production, and CIT yield in Monascus ruber by Wang et al. [126]. The results showed a decrease in CIT accumulation when high-intensity blue light (1500 lx) was used. However, no significant effect was observed under low-intensity blue light $(500 \mathrm{~lx})$. The low intensity of green light (500 lx) was also studied for its impact and was found to increase CIT production via the upregulation of certain genes such as mrl1, $\mathrm{mrl} 2$, pksCT, and ctnA [126].

\section{Detection Techniques}

\subsection{Sample Preparation}

Sample preparation for the detection of CIT involves a process of extraction and clean-up that plays an important role in analyzing CIT with improved sensitivity, precision, accuracy, and specificity. Extraction is mainly carried out using solvents like acetonitrile and methanol in combination with other salts such as sodium chloride, potassium chloride and citric acid, and solvents like formic acid, acetic acid, and water. Some extraction processes even involve acidification using undiluted hydrochloric acid, sulfuric acid, or phosphoric acid to improve recovery and reproducibility [17]. Further, various clean-up methods have been reported for purification of samples containing CIT, for example liquidliquid/solid extraction (LLE/LSE), dispersive liquid-liquid microextraction (DLLME), solid-phase extraction (SPE), immunoaffinity columns (IAC), and the quick, easy, cheap, effective, rugged, and safe method (QuEChERS) [127].

The LLE/LSE method for sample preparation is performed using polar organic solvents like ethanol, methanol, acetonitrile, and polyethylene glycol [128,129]. However, with this method, it is difficult to extract all analytes of interest with good recoveries, as they comprise of an extensive range of physicochemical properties. This method involves co-extraction of polar matrix components from the organic solvents used in the extraction process, thereby entailing a clean-up step. Thus, making the method unsafe due to the use of large amounts of toxic organic solvents, apart from making it time consuming and labor-intensive [130].

A fast and efficient extraction method DLLME uses small quantities of organic solvents in a three-component solvent system comprising a hydrophobic solvent (such as carbon tetrachloride), hydrophilic solvent (such as acetone), and an aqueous phase. In this method, 
the high surface area of hydrophobic solvent microdroplets expedites the extraction process followed by centrifugal separation of the analytes. However, the efficacy of this method for CIT sample preparation depends upon the nature of organic solvent being used, i.e., the ability to extract analytes of interest without significant contamination, lower solubility in aqueous samples, and compatibility with the instrument of analysis [131]. In SPE, the target analytes are retained in the solid media that are then recovered for analysis by solvent elution or thermal desorption. This method has several advantages over liquid extraction methods, for instance, higher selectivity and recovery, less solvent usage, and ease of online and offline automation. Commonly used sorbents that are used in the SPE method for the isolation of CIT include octadecylsiloxane-bonded silica sorbents ( $C_{18}$ phases), molecularly imprinted polymers (MIP), mixed-mode ion exchange resins, primary/secondary amines, and zirconia-coated silica [127].

Using the IAC method of sample preparation negates the effect of co-extraction of matrix interferences that is commonly found in liquid- and solid-phase extraction methods. This is done by immobilizing one of the interacting species (labelled as affinity ligand) on a solid support (for example, chitosan, silica, carbohydrate-related materials, sol-gel, and synthetic organic supports) through molecular recognition, followed by passing the sample over affinity sorbent. With this method, CIT is usually isolated using commercially available CitriTest IAC, which has improved sensitivity but accounts for strenuous and expensive production of antibodies [127]. However, using synthetic molecularly imprinted polymers can be an alternative, as they have better chemical and thermal stability along with higher extraction capacity [132]. Sample preparation using the QuEChERS method is carried out in two steps: (1) Extraction by establishing an equilibrium between the aqueous phase and organic phase based on salting-out; and (2) clean-up using dispersive solid-phase extraction (d-SPE). However, various studies have reported a modified QuEChERS method, where the clean-up is done by filtration [133]. Selective extraction of CIT has been reported to be carried out by using acetonitrile as a solvent due to its compatibility with the detection instrument (LC/MS) [127].

\subsection{Detection and Quantification Methods}

\subsubsection{Thin-Layer Chromatography (TLC)}

TLC uses visual or fluorodensitometry procedures with a recovery limit of $0.01 \mathrm{ppm}$ for quantitative as well as qualitative detection of mycotoxins, including the assessment of purity, separation, and the identification of organic compound heating [23]. In TLC, CIT separation is completed using various solvents, and the chemical validation of CIT is performed using two types of treatment approaches. The first involves saturation of TLC plate with acid-organic solution followed by exposing the TLC plate (with developed chromatogram) to the vapors of acetic anhydride/pyridine. The second treatment involves direct immersion of the TLC plate in an aluminum chloride reagent. These treatments transformed CIT into a new fluorescent compound that is detected under $365 \mathrm{~nm}$ light. However, with this method the fluorescence developed is weak and unstable. This yellow CIT fluorescence could be strengthened and sensitized and converted to blue by using another pre-treatment that involves aluminum chloride spray followed by heating [23]. CIT analysis using TLC has become limited, owing to its disadvantages of poor sensitivity and accuracy. Only Guo et al. [134] has recently studied the use of TLC for screening CIT in Liupao tea leaves inoculated with Penicillium citrinum strains.

\subsubsection{Colorimetric Technique of Detection}

Under visual detection, the colorimetric technique is one of the most common methods for CIT detection. The conjugated planar structure imparts a natural fluorescence to CIT, that can be evaluated qualitatively and quantitively using a fluorometer. This natural fluorescence can be further intensified in acidic environments [23]. Apart from this, other ultrasensitive methods for visual detection of CIT in the nano molar range have also been reported. For instance, carbon dot is the most recently identified luminescence material 
used as a fluorescence probe for CIT detection in picomole range [135]. The authors here revealed that diammonium citrate and urea synthesized the nitrogen-doped aqueous soluble carbon dot (CD) emitted in the yellow region. This onsite CIT visual detection sensing platform statically quenched the yellow fluorescence of CD in the presence of Congo red dye as CIT has a higher binding preference with CD as compared to Congo red. $\mathrm{Mg}^{2+}$ further expedited the reversion of red fluorescence of CD-Congo red assembly to yellow in the presence of contaminated samples containing CIT. This method is supposed to work well even in the presence of other mycotoxins, which is a common occurrence in contaminated samples and is reproducible, sensitive, and cost-effective.

\subsubsection{High-Performance Liquid Chromatography (HPLC)}

HPLC is one of the most common instrument-based techniques used to detect CIT in food and feed samples. It is usually combined with fluorescence, ultraviolet, and amperometric detection for high selectivity to achieve even low detection levels of CIT.

\subsubsection{Liquid Chromatography-Mass Spectroscopy (LC-MS)}

LC-MS is a high throughput analytical method for CIT detection with reduced costs, labor, and time. LC-MS/MS systems with a triple quadrupole analyzer (QqQ) is the most widely reported system used for the determination of CIT in food and feed samples. Apart from this, recently a high-resolution LC-MS/MS system coupled with Qtrap mass analyzer was reported for the detection of CIT due to its full-scan mode operation that provides high specificity irrespective of the number of other mycotoxins detected [136]. Similarly, Li et al. [137] reported lower values of limit of detection (LOD) and limit of quantitation (LOQ) by the UHPLC-MS/MS method (as compared to the HPLC-FLD method) in Chinese liupao tea, which demonstrated higher sensitivity of this method in CIT detection. LC coupled to multiple MS possesses numerous advantages for CIT detection, including increased sensitivity and selectivity, adaptability to different types of sample preparation methods, compatibility with a wide range of sample matrices, rapid acquisition, and higher confidence in CIT identification, confirmation, and quantification along with other mycotoxins with a single method at regulated levels [127]. Tangni et al. [138] harmonized CIT determination in food and food supplements made up of red yeast rice, wheat flour, and Ginkgo biloba leaves, and determined their homogeneity and stability using the LCMS/MS method. The analytical method proposed by the authors was found to be suitable and standardizable for citrinin determination at levels that could be contemplated by the European Commission.

\subsubsection{Liquid Chromatography Fluorescence Detection (LC-FLD)}

The natural fluorescence of CIT can be an effective alternative for its detection. Since only a few mycotoxins possess this property, this method cannot be used for multimycotoxin analysis. Typical excitation and emission wavelengths for CIT fluorescence detection have been reported to be 330-335 $\mathrm{nm}$ and 497-500 nm, respectively [127]. However, there have been instances where CIT in foods like red yeast rice [139] and coffee samples [140] could not be detected using this method, implying lower sensitivity and selectivity for CIT detection.

\subsubsection{Liquid Chromatography UV/Visible Detection (LC-UV/Vis)}

HPLC-UV/Vis is the least-reported method for CIT detection owing to its reduced selectivity and sensitivity than even fluorescence detection. However, since it is a simple and economical method, efforts can made to use this method in combination with a few pre-treatments for the estimation of CIT and other mycotoxins in food and feed.

\subsubsection{Enzyme-Linked Immunosorbent Assay (ELISA)}

ELISA kits represent a portable and easy-to-apply in CIT detection technique that is commonly being used owing to its lower costs and fast analysis. In an ELISA assay, 
a complex is formed due to a competitive assay that exists between the analyte and a specific primary antibody or a conjugate of an enzyme. This complex then interacts with the chromogenic substrate to determine the amount of analyte present [141]. The CitriTest ELISA kit is a commercially available ELISA-based CIT detection method that has been used for the analysis of food and feeds for a decade [127]. Apart from this, food samples are also analyzed for CIT by employing polyclonal and monoclonal antibodies [142]. However, as compared to monoclonal antibodies, polyclonal antibodies are cheaper and easier to produce, with the advantage of possessing more binding places on the antigen [141]. However, due to the tendency of polyclonal antibodies to cause cross reactivity in ELISA detection, this method for CIT estimation is not preferred. Recently, a method of CIT detection using ELISA was modified to a competitive indirect ELISA (ciELISA) format for grain-based food samples that had high specificity for CIT without any cross-reactivity with other mycotoxins [142]. The assay was developed with CIT-BTG (bovine thyroglobulin), as it had the best antibody titer and inhibition. This assay was also found to be nine times more sensitive than conventional ELISA [137]. To further increase the sensitivity of this method for CIT detection, Huang et al. [143] used an environmentally friendly signal amplification strategy of immuno-polymerase chain reaction (IPCR) that broadened the linear range as compared to phage ELISA.

\subsubsection{Immunochromatographic Assay (ICA)}

The properties of ICA make it a user-friendly method for CIT detection due to its suitability, simplicity, high speeds, and lower costs [144]. ICA assisted by molecularly imprinted biopolymers allows biological detection of multiple mycotoxins in contaminated agricultural products [145]. Commonly used molecularly imprinted biosensors using colloidal gold as a signal label have been found to possess insufficient sensitivity and cannot detect mycotoxins in lower concentrations. Thus, $\mathrm{Xu}$ et al. [146] improved the sensitivity of ICA by developing a dual fluorescent ICA (DF-ICA) using europium nanoparticles (EuNPs) due to its high fluorescence, long fluorescence lifetime, and non-toxic effects. The authors noted that the limits of detection $\left(\mathrm{IC}_{50}\right)$ were 0.06 and $0.11 \mathrm{ng} / \mathrm{mL}$ and the average recovery for simultaneous determination of CIT was in the range of 86.3 to $111.6 \%$. Similarly, a ratiometric detection strategy was introduced to improve the traditional molecularly imprinted electrochemical sensors that had limited practical applications due to their poor stability and reproducibility [147]. For CIT detection, Hu et al. [148] fabricated a sensor by electropolymerization with thionine as a monomer. Thionine and CIT anchorage were supported on the ample surface area provided by ionic liquid decorated boron and nitrogen co-doped hierarchical porous carbon (BN-HPC) as a supporter. With $\left[\mathrm{Fe}(\mathrm{CN})^{6}\right]^{3-/ 4-}$ adopted as an indicating probe, a wide range of CIT detection was provided with a recovery of 97 to $110 \%$.

\subsubsection{Capillary Zone Electrophoresis (CZE)}

The CZE method for detection of mycotoxins was developed in response to the drawbacks that were observed for the instrument-based (HPLC and GC) and biological detection methods (TLC, ELISA, and paper-based colloidal gold testing). Drawbacks of instrument-based methods include high costs, complex pre-treatments, time-intensiveness, and the usage of large amounts of organic solvents, while the drawbacks of biological methods are possible false-positive results, difficult reproducibility, and sensitivity [149]. CZE uses differences in the charge to size ratio in the electric field that ionizes CIT at a basic $\mathrm{pH}$ due to the presence of carboxylic groups in it [127]. CZE along with an ultraviolet detector (CZE-UV) was used to detect CIT along with other mycotoxins in pepper, with a comparison with the results obtained by using the previously validated method of HPLCFLD [150]. Satisfactory linearity was observed between the signal and CIT concentration (in the range 4.5 to $150 \mu \mathrm{g} / \mathrm{kg}$ ) with an LOD range of 0.3 to $2.5 \mu \mathrm{g} / \mathrm{kg}$. The authors revealed that the CZE-UV method was simple and quick, with higher analyte separation efficiency 
and sensitivity. In addition to this, CZE is a greener method as compared to LC, as it does not generate chemical waste [151].

\section{Masked Mycotoxins as a Major Concern in Detection}

The phenomena of growth of plants and fungi as well as the processing of foods bring about certain structural modifications in mycotoxins which lead to metabolites known as modified mycotoxins or masked mycotoxins. These modified mycotoxins can be either of the matrix-entrapment type (formed by physical dissolution or matric entrapment), or the chemically modified type (formed due to chemical or biological modifications) [152]. Some of the common modified toxins present in food crops like wheat, maize, and rice in substantial amounts include 3-acetyl-deoxynivalenol (3-acetyl-DON), deoxynivalenol-3glucoside (DON-3-G), and zearalenone-14-glucoside (ZEN-14-G) [153,154]. Consumption of these modified mycotoxins poses potential risks to human health [90]. Since the physical matrices and chemical derivatives of masked mycotoxins cannot be detected by routine analytical methods, it is difficult to further evaluate their toxicological impacts, thus making them untraceable [155].

CIT analysis based on existing methods is exigent owing to its poor reproducibility and comparability [127]. Hou and co-authors have very recently used a modified method of UPLC-FLD by including a pre-treatment step of acid hydrolysis that increased the CIT content in Hongqu significantly from $35.28 \%$ to $458.13 \%$ in CIT positive samples, thereby not only increasing the efficiency of fluorescence detection method but also unmasking the modified CIT that was believed to be matrix-associated (physically dissolved or trapped in the matrix compounds) in the contaminated food samples [155]. Thus, it can be implied that modified CIT (as a mycotoxin of concern) can be quantified using an appropriate combination of pre-treatment methods such as transformations using a hydrolytic process involving alkaline, acidic, and/or enzymatic methods [156,157]. In addition, integrated strategies of the analysis of masked forms mycotoxins, as suggested by Lu, et al. [158], could be applied for masked CIT to ensure proper detection and ultimately the safety and security of food and feed.

\section{Degradation Kinetics}

CIT contamination in food and feed can cause economic losses as well as concerns for human and animal health [159]. Therefore, suitable degradation and management strategies are crucial [160]. Different physical, chemical, and biological approaches are evaluated for the degradation and management of CIT at in-vivo and in-vitro conditions (Table 3). For physical methods, high-temperature treatment is the most common step during cooking for various purposes such as softening, taste improvement, degradation of toxic compounds, and sterilization. CIT is considered heat unstable and various chemical changes have been reported due to heat treatment at different conditions. Trivedi et al. [161] noted the partial degradation of CIT into less cytotoxic forms when heated with water above $120^{\circ} \mathrm{C}$. Further, boiling of CIT aqueous solution at 100 and $140{ }^{\circ} \mathrm{C}$ gradually degraded CIT into less toxic compounds, namely CIT-H1 and CIT-H2 [162]. The presence of moisture easily detoxified CIT at $140^{\circ} \mathrm{C}$, while the higher temperature was required to decompose at dry conditions. CIT degradation started at $160^{\circ} \mathrm{C}$ and was fully decomposed at $170{ }^{\circ} \mathrm{C}$ [112]. Dry heat did not cause any change in the CIT concentration of fermented red mold rice; however, heating in aqueous condition initially increased the CIT level, but with a further increase in temperature above $175{ }^{\circ} \mathrm{C}$, the CIT level decreased [163]. Besides heat, CIT is also light-sensitive. The application of white and blue light wavelengths completely degraded CIT content in in vivo conditions [164] and reduced about 79\% of CIT during fermentation and Monascus production [165].

Similarly, the chemical method employs various compounds for degradation purposes. A mixed solvent made up of phosphate-ethanol was reported to remove 91.6\% CIT content within 70 min from Monascus species-fermented red mold rice [163]. The addition of medium-chain fatty acids in the Monascus ruber culture medium inhibited the 
CIT production by the formation of hydrogen peroxide, and the pigment production was increased up to $50 \%$ [166]. Some flavonoids such as rutin, $\alpha$-glucosylrutin, or troxerutin were applied to the fermentation process which was initiated by Monascus aurantiacus Li AS3.4384. The addition of an equal amount $(5.0 \mathrm{~g} / \mathrm{L})$ of rutin, $\alpha$-glucosylrutin, or troxerutin degraded CIT content by $29.2 \%, 54.7 \%$, and $40.6 \%$, respectively. However, the CIT inhibition efficacy of troxerutin was between 53.7 and $87.9 \%$ at the end of the experiment, where the factor responsible for variation in CIT inhibition efficiency was the concentration of troxerutin and fermentation medium [117]. Besides this, absorbers are being used to tackle mycotoxins. For example, activated charcoal was found effective to ameliorate the toxic effect of mycotoxins including CIT when it was fed to broiler with feed. However, the combination of activated charcoal $(0.4 \%)$ and lyophilized yeast $(0.2 \%)$ culture exhibited higher efficacy in mitigation of mycotoxins [167]. An aqueous extract of mint inhibited up to $73 \%$ of the CIT produced from Penicillium citrinum, but did not inhibit fungal growth and the CIT reduction efficiency was concentration-dependent [168].

Hence, due to several limitations of physical and chemical methods, various biological methods as alternatives have been examined for CIT degradation. Several microorganisms can degrade CIT. CIT is nephrotoxic, causes damage to genetic material, and alters the differentially expressed proteins. However, proteomes and transcriptomes of Cryptococcus podzolicus Y3, when treated with $10 \mu \mathrm{g} / \mathrm{mL}$ CIT, exhibited defense responses and drug metabolism, and consequently degraded CIT [160]. The degradation of CIT by C. podzolicus Y3 is due to its intracellular enzyme(s), not by uptake or adsorption of CIT. The degradation of CIT is dependent on various factors such as time, temperature, concertation of cells, and $\mathrm{pH}$ [169]. In in vivo conditions, Rhodotorula mucilaginosa significantly $(93.10 \%)$ degraded CIT produced by P. digitatum in the $48 \mathrm{~h}$ of the experiment [170]. Aspergillus, Cladosporium, and Penicillium are the major genera that infect the paddy rice and produce CIT during storage. The addition of Trichoderma hamatum in in vivo conditions significantly reduced the population of Penicillium viridicatum and inhibited CIT content [171]. Further, Klebsiella pneumoniae strain NPUST-B11 isolated from soil sample was effective in degrading CIT [172]. In addition, Kanpiengjai et al. [173] collected 96 bacterial strains from various sources in which Rhizobium borbori PS45 and E. cloacae PS21 were found to be effective for CIT degradation. However, the efficacy of microorganisms for CIT degradation depends on the concentration, $\mathrm{pH}$, temperature, and substrate used [170].

Table 3. Various degradation methods for controlling citrinin in food and feed.

\begin{tabular}{|c|c|c|c|}
\hline Degradation Methods & Experimental Details & Key Findings & References \\
\hline \multicolumn{4}{|c|}{ Physical } \\
\hline Light (Blue light) & Monascus production & $\begin{array}{c}\text { Decreased CIT by } 79 \% ; 28.5 \% \text { increase in } \\
\text { pigment production }\end{array}$ & {$[165]$} \\
\hline Blue light & In vivo & Blue light completely degraded the CIT & [164] \\
\hline Temperature/Heat & $\begin{array}{c}\text { Heating under aquous condition } \\
\text { Temperature: } 90-130{ }^{\circ} \mathrm{C} \\
\text { Time: } 10-20 \mathrm{~min}\end{array}$ & $\begin{array}{l}\text { Partial degradation and formation of } \\
\text { low cytotoxic substances; increase in } \\
\text { temperature and time above } 120^{\circ} \mathrm{C} \text { to } \\
\text { form another less cytotoxic substance }\end{array}$ & {$[161]$} \\
\hline Heating/boiling & $\begin{array}{c}\text { Heating at } 100-140^{\circ} \mathrm{C} \text { in aqueous } \\
\text { medium }\end{array}$ & $\begin{array}{l}\text { High-temperature treatment degraded } \\
\text { CIT into CIT H1 and H2 }\end{array}$ & [162] \\
\hline High hydrostatic pressure (HHP) & $\begin{array}{c}\text { Time: } 5 \mathrm{~min} \\
\text { Pressure: } 250 \mathrm{MPa} \\
\text { Temperature: } 35 \pm 1{ }^{\circ} \mathrm{C}\end{array}$ & $\begin{array}{c}90-100 \% \text { of the microbial population } \\
\text { was reduced; the CIT level was reduced } \\
\text { up to } 100 \% \text {; increased phenolic } \\
\text { compounds; enhanced } \\
\text { antioxidant activity }\end{array}$ & {$[118]$} \\
\hline Cold atmospheric pressure plasma & $\begin{array}{l}\text { Power output: } 50 \mathrm{kV}, 100 \text { watts } \\
\text { Electron frequency: } 30 \mathrm{kHz} \\
\text { Gas flow: } 6 \mathrm{~L} / \mathrm{min}\end{array}$ & $\begin{array}{c}\text { Reduced } 50 \% \text { of CIT; no negative effect } \\
\text { on nutrients }\end{array}$ & {$[121]$} \\
\hline Magnetic nanoparticles & & $\begin{array}{c}\text { Formation of a CIT-nanoparticle } \\
\text { complex; effective in CIT removal; can } \\
\text { be used in the food industry; is difficult } \\
\text { to operate on a large scale }\end{array}$ & {$[174]$} \\
\hline
\end{tabular}


Table 3. Cont.

\begin{tabular}{|c|c|c|c|}
\hline Degradation Methods & Experimental Details & Key Findings & References \\
\hline Ultrasonication & $\begin{array}{c}\text { Power: } 250 \mathrm{~W} \\
\text { Liquid: solid ratio } 40: 1 \\
\text { Time: } 50.7 \text { min, temperature: } 20{ }^{\circ} \mathrm{C}\end{array}$ & $\begin{array}{c}\text { Removed up to } 87.7 \% \text { CIT from red } \\
\text { yeast rice }\end{array}$ & {$[120]$} \\
\hline \multicolumn{4}{|c|}{ Chemical } \\
\hline Ozone & $\begin{array}{c}\mathrm{O}_{3} \text { treatment: }(40 \text { and } 60 \mu \mathrm{mol} / \mathrm{mol} \\
\text { Time: } 180 \mathrm{~min}\end{array}$ & $\begin{array}{l}\text { CIT level reduced from } 173.51 \mu \mathrm{g} / \mathrm{kg} \text { to } \\
42.90 \mu \mathrm{g} / \mathrm{kg} 180 \mathrm{~min} \text { after treatment }\end{array}$ & [175] \\
\hline Medium-chain fatty acids & $\begin{array}{l}\text { In vivo } \\
\text { Monascus ruber }\end{array}$ & $\begin{array}{l}\text { Improved pigment formation; reduced } \\
\text { CIT production in the process }\end{array}$ & [166] \\
\hline Flavanoids & Monascus aurantiacus Li AS3.4384 & Inhibition of CIT formation up to $87.9 \%$ & [117] \\
\hline $\begin{array}{l}\text { Monascus species-fermented red } \\
\text { mold rice }\end{array}$ & $\begin{array}{l}45 \% \text { ethanol, } 1.5 \% \text { phosphate, and } \\
\text { extraction for } 70 \mathrm{~min}\end{array}$ & $\begin{array}{c}\text { Reduced CIT level by } 91.6 \% \text {; maintained } \\
79.5 \% \text { monacolin K }\end{array}$ & [163] \\
\hline \multicolumn{4}{|c|}{ Biological } \\
\hline Genistein & $\begin{array}{l}\text { Monascus mold (used to produce } \\
\text { Monascus pigments, monacolin K, } \\
\text { and ergosterol) }\end{array}$ & $\begin{array}{l}\text { Suppressed acetyl- CoA formation; } \\
\text { reduced CIT content; reduced } \\
\text { significant differential metabolites }\end{array}$ & [176] \\
\hline Cryptococcus podzolicus Y-3 cells & - & $\begin{array}{l}\text { In response to CIT stress, DNA repair, } \\
\text { antioxidative activity, and the TCA cycle } \\
\text { were activated; degradation of CIT }\end{array}$ & [160] \\
\hline Cryptococcus podzolicus Y3 & - & $\begin{array}{l}\text { Degradation up to } 98 \% \text {; intracellular } \\
\text { enzyme caused degradation; } \\
\text { degradation into less toxic compounds; } \\
\text { degradation was factor-dependent }\end{array}$ & [169] \\
\hline Rhodotorula mucilaginosa & - & $\begin{array}{c}\text { Degradaded CIT by } 91.67 \% \text { at pH } 4.0 \\
\text { and } 28{ }^{\circ} \mathrm{C} \text {; degradation was } \\
\text { factor-dependent }\end{array}$ & [170] \\
\hline $\begin{array}{l}\text { Klebsiella pneumoniae strain } \\
\text { NPUST-B11 }\end{array}$ & - & $\begin{array}{l}\text { Ful degradation of CIT after } 10 \mathrm{~h} \\
\text { of incubation. }\end{array}$ & [172] \\
\hline Rhizobium borborid & $\begin{array}{l}\text { Temperature: } 30^{\circ} \mathrm{C} \\
\text { Time: } 120 \mathrm{~h}\end{array}$ & $\begin{array}{l}\text { R. borbori PS } 45 \text { and E. cloacae PS } 21 \text { were } \\
\text { found to be the most promising among } \\
\text { the collected strains; they caused } 63.4 \% \\
\text { and } 43.6 \% \text { reduction, respectively }\end{array}$ & {$[173]$} \\
\hline Adsorbents & $\begin{array}{c}\text { Activated charcoal and } 0.4 \% \\
\text { lyophilized yeast culture }(0.2 \%) \\
\text { with feed }\end{array}$ & $\begin{array}{l}\text { Ameliorated toxic effect of mycotoxin } \\
\text { to broilers }\end{array}$ & {$[167]$} \\
\hline
\end{tabular}

\section{Management and Control Strategies}

CIT is mainly produced by members of the genus Aspergillus and Penicillium. Fruits or grains may get infected by these microorganisms at any stage: pre-harvest (cultivation, cultural operations), during harvest, and post-harvest (handling, processing, or storage) conditions. These can be managed at the field level by adopting good agricultural practices (GAPs), good manufacturing practices (GMPs), and good storage practices (GSPs) such as the selection of resistant cultivars/varieties, nutrient management, floor management, clean cultivation, proper weeding and tillage operations, the application of optimum level of plant protection chemicals, and harvesting at the proper maturity stage. After harvest, proper handling, adequate moisture, and suitable storage conditions are helpful to mitigate mycotoxins [177-182] Ostry et al. [133] reported the natural occurrence of CIT in grapes. They identified 23 strains of Penicillium expansum in 25 samples of grapes. Some of them were responsible for the production of CIT. The authors recommended proper monitoring of fungal colonization in the field and during harvesting because mycotoxins make fresh produce unfit for consumption and may not be degraded properly during processing. For their management, some chemical and biological approaches can be adopted, as discussed in the earlier section.

Commercial fungicides such as Aliette, Rovral, Cantus, Ortiva, Luna Experience, Fenomenal, and Mancozeb are beneficial to inhibit the growth of filamentous fungi at the pre-harvest stage. However, sometimes plant protection chemicals can induce the formation of mycotoxins [183]. Postharvest benzo-(1,2,3)-thiadiazole-7-carbothioic acid S-methyl ester (BTH) treatment of peach prevents the infection of Penicillium expansum [184]. 
However, some fungi develop resistance against fungicides, thereby raising concerns [185]. Hence there is a need for better alternatives.

Harvesting at the right maturity stage and proper handling reduce the bruising injury. Similarly, proper grading for selecting good quality products by culling damaged and overripe products can mitigate the chance of microbial contamination. Further, postharvest contamination of fungal infection can be successfully inhibited using plant extracts such as jasmonates [186]; cinnamon bark extract [186]; pomegranate peel extract [187]; essential oils from Citrus aurantium [188]; clove oil [189]; the application of irradiation [190-193]; hot water treatment (HWT) [194]; salts [195,196]; mixed treatments such as the use of sodium salts with HWT [197]; salts and wax [198]; the use of biocontrol agents [199,200], and the combination of HWT and Debaryomyces hansenii [201]. In the post-harvest phase, a proper storage facility, cleanliness, and the right moisture level are also crucial. Dust and left out stored material may act as an inoculum and can be a source of infection in the subsequent storage materials. Tangni and Pussemier [3] reported that the dust contains about 137-344 ng/g CIT and the presence of dust material in storage may cause CIT contamination in stored wheat grain. The mycotoxicity depends on the water activity of grain and the mycotoxigenic potential of inoculants. Moisture condensation and migration were observed in wheat grain even when stored below the threshold of $14.5 \%$ moisture. Furthermore, the nature of the condensation affected P. verrucosum contamination and CIT formation [79]. Application of ozone in stored food grain inhibits the growth of Aspergillus flavus and Penicillium citrinum and the formation of mycotoxin [175]. CIT contamination and concentration can also be managed during processing by adopting the principle of HACCP. The selection of suitable microbial strains and alterations of suitable substrates for fermentation significantly inhibit CIT concentration in the end product. Marič et al. [8] found that the 'EBY-3' strain of Monascus purpureus produced the highest pigment yield and inhibited CIT formation after 21 days of fermentation process when rice was used as substrate. Furthermore, the application of some natural products like mint extract [168] and neem leaf extract [202] have been reported to inhibit CIT production. The use of Zataria multiflora Boiss essential oil inhibited the growth of P. citrinum in lab conditions and CIT production in cheese [203,204]. A similar finding was also reported with the application of eugenol and thymol in Spanish cheese [205].

\section{Conclusions}

Consumption of citrinin-contaminated food and feed by both humans and animals has led to serious health concerns across the globe. The toxin could enter the food chains by contaminating the food and feed at any stage of agricultural practice and in pre/postharvest conditions. Due to the nephrotoxic and genotoxic nature of CIT, the health of both humans and animals is at greater risk. Therefore, proper Hazard Analysis Critical Control Point (HACCP) plans, Good Agricultural Practices (GAPs), and Good Manufacturing Practice (GMPs) could be effective in controlling the toxins during various agriculture and processing stages. In addition, various physical, chemical, and biological methods could be implemented to degrade and mitigate CIT production and contamination, thereby preventing its entry into the food chain. Further, the toxin is reported to degrade into various forms and exists in masked forms. Hence, rapid and precise detection methods become essential as well as challenging in terms of their identification, quantification, and mitigation. This highlights the necessity of concise and reliable detection methods for their management. Limited information is available on the masked forms of CIT in food and feed, and these forms are likely to remain undetected and under-reported, thereby presenting a hidden threat to food safety and security. Hence, future research should emphasize an in-depth investigation of the masked forms of CIT to obtain easy, rapid, and precise detection and mitigation strategies.

Author Contributions: P.K., M.K. (Madhu Kamle), and D.K.M. conceived and designed the manuscript; A.G., S.P., N.S., B.S., S.M., S.A., R.S., V.S., J.D.-L. and S.B. wrote the manuscript; M.K. (Madhu Kamle), D.K.M., P.K. and A.K. supported the editing of the manuscript; P.K., M.K. (Manoj Kumar), A.K. and 
S.G. critically reviewed and did the required editing of the manuscript. All authors have read and agreed to the published version of the manuscript.

Funding: No external funding received for this work.

Institutional Review Board Statement: Not applicable.

Informed Consent Statement: Not applicable.

Data Availability Statement: Not applicable.

Acknowledgments: The authors are grateful to their respective higher authorities, departments, institutions, and universities for their support and co-operation. Figure 2 was reproduced from Ref. [5] (He, Y.; Cox, R.J. The molecular steps of citrinin biosynthesis in fungi. Chem. Sci. 2016, 7, 2119-2127) with permission from the Royal Society of Chemistry. Authors are highly thankful to Royal society of chemistry for help and support.

Conflicts of Interest: The authors declare no conflict of interest.

\section{References}

1. Dalefield, R. Mycotoxins and mushrooms. In Veterinary Toxicology for Australia and New Zealand; Elsevier: Amsterdam, The Netherlands, 2017; pp. 373-419.

2. Kováč, Š.; Nemec, P.; Betina, V.; Balan, J. Chemical structure of citrinin. Nature 1961, 190, 1104-1105. [CrossRef]

3. Tangni, E.K.; Pussemier, L. Ochratoxin A and citrinin loads in stored wheat grains: Impact of grain dust and possible prediction using ergosterol measurement. Food Addit. Contam. 2006, 23, 181-189. [CrossRef] [PubMed]

4. Ostry, V.; Malir, F.; Ruprich, J. Producers and important dietary sources of ochratoxin A and citrinin. Toxins 2013, 5, 1574-1586. [CrossRef]

5. He, Y.; Cox, R.J. The molecular steps of citrinin biosynthesis in fungi. Chem. Sci. 2016, 7, 2119-2127. [CrossRef] [PubMed]

6. Pitt, J.I. Biology and ecology of toxigenic Penicillium species. Adv. Exp. Med. Biol. 2002, 504, $29-41$.

7. Pattanagul, P.; Pinthong, R.; Phianmongkhol, A.; Tharatha, S. Mevinolin, citrinin and pigments of adlay angkak fermented by Monascus sp. Int. J. Food Microbiol. 2008, 126, 20-23. [CrossRef] [PubMed]

8. Marič, A.; Skočaj, M.; Likar, M.; Sepčić, K.; Cigić, I.K.; Grundner, M.; Gregori, A. Comparison of lovastatin, citrinin and pigment production of different Monascus purpureus strains grown on rice and millet. J. Food Sci. Technol. 2019, 56, 3364-3373. [CrossRef]

9. Gil-Serna, J.; Vázquez, C.; González-Jaén, M.T.; Patiño, B. Mycotoxins toxicology. In Encyclopedia of Food Microbiology, 2nd ed.; Batt, C.A., Tortorello, M.A., Eds.; Academic Press: Cambridge, MA, USA, 2014; pp. 887-892. [CrossRef]

10. Kumar, P.; Mahato, D.K.; Kamle, M.; Mohanta, T.K.; Kang, S.G. Aflatoxins: A global concern for food safety, human health and their management. Front. Microbiol. 2017, 7, 2170. [CrossRef]

11. Erdoğrul, Ö.; Azirak, S. Review of the studies on the red yeast rice (Monascus purpureus). Turk. Electron. J. Biotechnol. 2004, 2, 37-49.

12. Chang, C.-H.; Yu, F.-Y.; Wang, L.-T.; Lin, Y.-S.; Liu, B.-H. Activation of ERK and JNK signaling pathways by mycotoxin citrinin in human cells. Toxicol. Appl. Pharmacol. 2009, 237, 281-287. [CrossRef]

13. Nakajima, Y.; Iguchi, H.; Kamisuki, S.; Sugawara, F.; Furuichi, T.; Shinoda, Y. Low doses of the mycotoxin citrinin protect cortical neurons against glutamate-induced excitotoxicity. J. Toxicol. Sci. 2016, 41, 311-319. [CrossRef] [PubMed]

14. De Oliveira Filho, J.W.G.; Islam, M.T.; Ali, E.S.; Uddin, S.J.; de Oliveira Santos, J.V.; de Alencar, M.V.O.B.; Júnior, A.L.G.; Paz, M.F.C.J.; de Brito, M.d.R.M.; de Sousa, J.M.d.C. A comprehensive review on biological properties of citrinin. Food Chem. Toxicol. 2017, 110, 130-141. [CrossRef]

15. Nejati, P.; Chaychi Nosrati, A.; Bayat, M. An investigation on measurement means of Citrinin toxin quantity by toxigenic Aspergillus species in biomass, using ELISA. Int. J. Adv. Biol. Biomed. Res. 2014, 2, 2466-2471.

16. Jeswal, P.; Kumar, D. Mycobiota and natural incidence of aflatoxins, ochratoxin A, and citrinin in Indian spices confirmed by LC-MS/MS. Int. J. Microbiol. 2015, 1-8. [CrossRef] [PubMed]

17. Silva, L.J.G.; Pereira, A.M.P.T.; Pena, A.; Lino, C.M. Citrinin in foods and supplements: A review of occurrence and analytical methodologies. Foods 2021, 10, 14. [CrossRef] [PubMed]

18. Hackbart, H.; Prietto, L.; Primel, E.G.; Garda-Buffon, J.; Badiale-Furlong, E. Simultaneous extraction and detection of ochratoxin A and citrinin in rice. J. Braz. Chem. Soc. 2012, 23, 103-109. [CrossRef]

19. Trivedi, A.B.; Hirota, M.; Doi, E.; Kitabatake, N. Formation of a new toxic compound, citrinin H1, from citrinin on mild heating in water. J. Chem. Soc. Perkin Trans. 1 1993, 1, 2167-2171. [CrossRef]

20. Li, Y.-P.; Xu, Y.; Huang, Z.-B. Isolation and characterization of the citrinin biosynthetic gene cluster from Monascus aurantiacus. Biotechnol. Lett. 2012, 34, 131-136. [CrossRef]

21. Chai, X.; Ai, Z.; Liu, J.; Guo, T.; Wu, J.; Bai, J.; Lin, Q. Effects of pigment and citrinin biosynthesis on the metabolism and morphology of Monascus purpureus in submerged fermentation. Food Sci. Biotechnol. 2020, 29, 927-937. [CrossRef]

22. Chen, Y.-P.; Tseng, C.-P.; Chien, I.-L.; Wang, W.-Y.; Liaw, L.-L.; Yuan, G.-F. Exploring the distribution of citrinin biosynthesis related genes among Monascus species. J. Agric. Food Chem. 2008, 56, 11767-11772. [CrossRef] 
23. Zhang, H.; Ahima, J.; Yang, Q.; Zhao, L.; Zhang, X.; Zheng, X. A review on citrinin: Its occurrence, risk implications, analytical techniques, biosynthesis, physiochemical properties and control. Food Res. Int. 2020, 141, 110075. [CrossRef] [PubMed]

24. Shimizu, T.; Kinoshita, H.; Ishihara, S.; Sakai, K.; Nagai, S.; Nihira, T. Polyketide synthase gene responsible for citrinin biosynthesis in Monascus purpureus. Appl. Environ. Microbiol. 2005, 71, 3453-3457. [CrossRef] [PubMed]

25. Fu, G.; Xu, Y.; Li, Y.; Tan, W. Construction of a replacement vector to disrupt pksCT gene for the mycotoxin citrinin biosynthesis in Monascus aurantiacus and maintain food red pigment production. Asia Pac. J. Clin. Nutr. 2007, 16, 137-142. [PubMed]

26. Shimizu, T.; Kinoshita, H.; Nihira, T. Identification and in vivo functional analysis by gene disruption of ctnA, an activator gene involved in citrinin biosynthesis in Monascus purpureus. Appl. Environ. Microbiol. 2007, 73, 5097-5103. [CrossRef]

27. Liang, B.; Du, X.-J.; Li, P.; Sun, C.-C.; Wang, S. Investigation of citrinin and pigment biosynthesis mechanisms in Monascus purpureus by transcriptomic analysis. Front. Microbiol. 2018, 9, 1374. [CrossRef]

28. EFSA. European food safety authority panel on contaminants in the food chain. Scientific opinion on the risks for public and animal health related to the presence of citrinin in food and feed. EFSA J. 2012, 10, 2605.

29. Smith, M.-C.; Madec, S.; Coton, E.; Hymery, N. Natural co-occurrence of mycotoxins in foods and feeds and their in vitro combined toxicological effects. Toxins 2016, 8, 94. [CrossRef]

30. Bailly, J.D.; Querin, A.; Le Bars-Bailly, S.; Benard, G.; Guerre, P. Citrinin production and stability in cheese. J. Food Prot. 2002, 65, 1317-1321. [CrossRef]

31. Arroyo-Manzanares, N.; Huertas-Pérez, J.F.; García-Campaña, A.M.; Gámiz-Gracia, L. Simple methodology for the determination of mycotoxins in pseudocereals, spelt and rice. Food Control 2014, 36, 94-101. [CrossRef]

32. Lhotská, I.; Šatínský, D.; Havlíková, L.; Solich, P. A fully automated and fast method using direct sample injection combined with fused-core column on-line SPE-HPLC for determination of ochratoxin A and citrinin in lager beers. Anal. Bioanal. Chem. 2016, 408, 3319-3329. [CrossRef]

33. Martins, M.L.; Gimeno, A.; Martins, H.M.; Bernardo, F. Co-occurrence of patulin and citrinin in Portuguese apples with rotten spots. Food Addit. Contam. 2002, 19, 568-574. [CrossRef] [PubMed]

34. Wang, M.; Jiang, N.; Xian, H.; Wei, D.; Shi, L.; Feng, X. A single-step solid phase extraction for the simultaneous determination of 8 mycotoxins in fruits by ultra-high performance liquid chromatography tandem mass spectrometry. J. Chromatogr. A 2016, 1429, 22-29. [CrossRef] [PubMed]

35. Pepeljnjak, S.; Šegvic, M.; Ozegovic, L. Citrininotoxinogenicity of Penicillium spp. isolated from decaying apples. Braz. J. Microbiol. 2002, 33, 134-137. [CrossRef]

36. Arroyo-Manzanares, N.; Huertas-Pérez, J.F.; Gámiz-Gracia, L.; García-Campaña, A.M. A new approach in sample treatment combined with UHPLC-MS/MS for the determination of multiclass mycotoxins in edible nuts and seeds. Talanta 2013, 115, 61-67. [CrossRef] [PubMed]

37. Kumar, M. Quantitative estimation of aflatoxins, ochratoxin and citrinin in dried fruits and nuts samples from Indo-Gangetic region of Bihar. Int. J. Adv. Res. Innov. Ideas Educ. 2019, 5, 2395-4396.

38. Polisenska, I.; Pfohl-Leszkowicz, A.; Hadjeba, K.; Dohnal, V.; Jirsa, O.; Denesova, O.; Jezkova, A.; Macharackova, P. Occurrence of ochratoxin A and citrinin in Czech cereals and comparison of two HPLC methods for ochratoxin A detection. Food Addit. Contam. 2010, 27, 1545-1557. [CrossRef]

39. Heperkan, D.; Meric, B.E.; Sismanoglu, G.; Dalkiliç, G.; Güler, F.K. Mycobiota, mycotoxigenic fungi, and citrinin production in black olives. In Advances in Food Mycology; Springer: Berlin/Heidelberg, Germany, 2006; pp. 203-210.

40. El Adlouni, C.; Tozlovanu, M.; Naman, F.; Faid, M.; Pfohl-Leszkowicz, A. Preliminary data on the presence of mycotoxins (ochratoxin A, citrinin and aflatoxin B1) in black table olives "Greek style" of Moroccan origin. Mol. Nutr. Food Res. 2006, 50, 507-512. [CrossRef]

41. Čulig, B.; Bevardi, M.; Bošnir, J.; Serdar, S.; Lasić, D.; Racz, A.; Galić, A.; Kuharić, Ž. Presence of citrinin in grains and its possible health effects. Afr. J. Tradit. Complement. Altern. Med. 2017, 14, 22-30. [CrossRef]

42. Molinié, A.; Faucet, V.; Castegnaro, M.; Pfohl-Leszkowicz, A. Analysis of some breakfast cereals on the French market for their contents of ochratoxin A, citrinin and fumonisin B1: Development of a method for simultaneous extraction of ochratoxin A and citrinin. Food Chem. 2005, 92, 391-400. [CrossRef]

43. Tabata, S.; Iida, K.; Kimura, K.; Iwasaki, Y.; Nakazato, M.; Kamata, K.; Hirokado, M. Investigation of ochratoxin A, B and citrinin contamination in various commercial foods. Shokuhin Eiseigaku Zasshi 2008, 49, 111-115. [CrossRef]

44. Markov, K.; Pleadin, J.; Bevardi, M.; Vahčić, N.; Sokolić-Mihalak, D.; Frece, J. Natural occurrence of aflatoxin B1, ochratoxin A and citrinin in Croatian fermented meat products. Food Control 2013, 34, 312-317. [CrossRef]

45. Kiebooms, J.A.L.; Huybrechts, B.; Thiry, C.; Tangni, E.K.; Callebaut, A. A quantitative UHPLC-MS/MS method for citrinin and ochratoxin A detection in food, feed and red yeast rice food supplements. World Mycotoxin J. 2016, 9, 343-352. [CrossRef]

46. Wawrzyniak, J.; Waśkiewicz, A. Ochratoxin A and citrinin production by Penicillium verrucosum on cereal solid substrates. Food Addit. Contam. Part A 2014, 31, 139-148. [CrossRef] [PubMed]

47. Odhav, B.; Naicker, V. Mycotoxins in South African traditionally brewed beers. Food Addit. Contam. 2002, 19, 55-61. [CrossRef]

48. Oztas, E.; Ozden, H.; Ozhan, G. A preliminary survey of citrinin contamination in dried fruits, molasses and liquorice products in Turkey. J. Food Nutr. Res. 2020, 59, 81-86. 
49. Ojuri, O.T.; Ezekiel, C.N.; Eskola, M.K.; Šarkanj, B.; Babalola, A.D.; Sulyok, M.; Hajšlová, J.; Elliott, C.T.; Krska, R. Mycotoxin co-exposures in infants and young children consuming household-and industrially-processed complementary foods in Nigeria and risk management advice. Food Control 2019, 98, 312-322. [CrossRef]

50. Ruan, C.; Diao, X.; Li, N.; Zhang, H.; Pang, Y.; Liu, C. Determination of ochratoxin A and citrinin in fruits using ultrasoundassisted solvent extraction followed by dispersive liquid-liquid microextraction with HPLC with fluorescence detection. Anal. Methods 2016, 8, 1586-1594. [CrossRef]

51. Guo, B.Y.; Wang, S.; Ren, B.; Li, X.; Qin, F.; Li, J. Citrinin selective molecularly imprinted polymers for SPE. J. Sep. Sci. 2010, 33, 1156-1160. [CrossRef]

52. Sato, T.; Higashihara, K.; Sasaki, A.; Toth, D.; Goto, T. Development and single laboratory validation of a method for citrinin. World Mycotoxin J. 2010, 3, 129-134. [CrossRef]

53. Xue-Mei, L.; Xing-Hai, S.; Lan, X.; Zhen-Wen, D.; Shu-Ren, G. A validated RP-HPLC method for the determination of citrinin in xuezhikang capsule and other Monascus-fermented products. E-J. Chem. 2012, 9, 260-266. [CrossRef]

54. Hajnal, E.J.; Kos, J.; Malachová, A.; Steiner, D.; Stranska, M.; Krska, R.; Sulyok, M. Mycotoxins in maize harvested in Serbia in the period 2012-2015. Part 2: Non-regulated mycotoxins and other fungal metabolites. Food Chem. 2020, 317, 126409. [CrossRef] [PubMed]

55. Kong, D.; Xie, Z.; Liu, L.; Song, S.; Kuang, H. Development of ic-ELISA and lateral-flow immunochromatographic assay strip for the detection of citrinin in cereals. Food Agric. Immunol. 2017, 28, 754-766. [CrossRef]

56. Warth, B.; Parich, A.; Atehnkeng, J.; Bandyopadhyay, R.; Schuhmacher, R.; Sulyok, M.; Krska, R. Quantitation of mycotoxins in food and feed from Burkina Faso and Mozambique using a modern LC-MS/MS multitoxin method. J. Agric. Food Chem. 2012, 60, 9352-9363. [CrossRef] [PubMed]

57. Santos, L.; Marín, S.; Sanchis, V.; Ramos, A.J. Screening of mycotoxin multicontamination in medicinal and aromatic herbs sampled in Spain. J. Sci. Food Agric. 2009, 89, 1802-1807. [CrossRef]

58. Ali, N. Co-occurrence of citrinin and ochratoxin A in rice in Asia and its implications for human health. J. Sci. Food Agric. 2018, 98, 2055-2059. [CrossRef]

59. Samsudin, N.I.P.; Abdullah, N. A preliminary survey on the occurrence of mycotoxigenic fungi and mycotoxins contaminating red rice at consumer level in Selangor, Malaysia. Mycotoxin Res. 2013, 29, 89-96. [CrossRef]

60. Zhou, Y.; Chen, J.; Dong, L.; Lu, L.; Chen, F.; Hu, D.; Wang, X. A study of fluorescence properties of citrinin in $\beta$-cyclodextrin aqueous solution and different solvents. J. Lumin. 2012, 132, 1437-1445. [CrossRef]

61. Arévalo, F.J.; Granero, A.M.; Fernández, H.; Raba, J.; Zón, M.A. Citrinin (CIT) determination in rice samples using a micro fluidic electrochemical immunosensor. Talanta 2011, 83, 966-973. [CrossRef]

62. Zhu, D.; Zhang, H.; Bing, X. Preparation of an immunoaffinity column for the clean-up of fermented food samples contaminated with citrinin. Food Addit. Contam. Part A 2013, 30, 389-394. [CrossRef]

63. Gordon, R.Y.; Cooperman, T.; Obermeyer, W.; Becker, D.J. Marked variability of monacolin levels in commercial red yeast rice products: Buyer beware! Arch. Intern. Med. 2010, 170, 1722-1727. [CrossRef]

64. Wu, C.-L.; Kuo, Y.-H.; Lee, C.-L.; Hsu, Y.-W.; Pan, T.-M. Synchronous high-performance liquid chromatography with a photodiode array detector and mass spectrometry for the determination of citrinin, monascin, ankaflavin, and the lactone and acid forms of monacolin K in red mold rice. J. AOAC Int. 2011, 94, 179-190. [CrossRef] [PubMed]

65. Ji, X.; Xu, J.; Wang, X.; Qi, P.; Wei, W.; Chen, X.; Li, R.; Zhou, Y. Citrinin determination in red fermented rice products by optimized extraction method coupled to liquid chromatography tandem mass spectrometry (LC-MS/MS). J. Food Sci. 2015, 80, T1438-T1444 [CrossRef] [PubMed]

66. Wang, W.; Chen, Q.; Zhang, X.; Zhang, H.; Huang, Q.; Li, D.; Yao, J. Comparison of extraction methods for analysis of citrinin in red fermented rice. Food Chem. 2014, 157, 408-412. [CrossRef] [PubMed]

67. Mornar, A.; Sertić, M.; Nigović, B. Development of a rapid LC/DAD/FLD/MS n method for the simultaneous determination of monacolins and citrinin in red fermented rice products. J. Agric. Food Chem. 2013, 61, 1072-1080. [CrossRef] [PubMed]

68. Li, Y.; Wu, H.; Guo, L.; Zheng, Y.; Guo, Y. Microsphere-based flow cytometric immunoassay for the determination of citrinin in red yeast rice. Food Chem. 2012, 134, 2540-2545. [CrossRef]

69. Liu, R.; Xu, B. Optimization of extraction conditions of citrinin from red yeast rice by orthogonal design and quantification of citrinin by high-performance liquid chromatography. Food Anal. Methods 2013, 6, 677-682. [CrossRef]

70. Meng, W.; Zhu, L.X.; Guo, X.M.; Li, K.H.; Liu, R.R. Determination of citrinin in red yeast rice by high performance liquid chromatography with immuno-affinity column. In Proceedings of Advanced Materials Research; Trans Tech Publications Ltd.: Bäch, Switzerland; pp. 353-356.

71. Nigović, B.; Sertić, M.; Mornar, A. Simultaneous determination of lovastatin and citrinin in red yeast rice supplements by micellar electrokinetic capillary chromatography. Food Chem. 2013, 138, 531-538. [CrossRef]

72. Nguyen, M.T.; Tozlovanu, M.; Tran, T.L.; Pfohl-Leszkowicz, A. Occurrence of aflatoxin B1, citrinin and ochratoxin A in rice in five provinces of the central region of Vietnam. Food Chem. 2007, 105, 42-47. [CrossRef]

73. Nazari, F.; Sulyok, M.; Yazdanpanah, H.; Kobarfard, F.; Krska, R. A survey of mycotoxins in domestic rice in Iran by liquid chromatography tandem mass spectrometry. Toxicol. Mech. Methods 2014, 24, 37-41. [CrossRef] 
74. Huertas-Pérez, J.F.; Arroyo-Manzanares, N.; García-Campaña, A.M.; Gámiz-Gracia, L. High-throughput determination of citrinin in rice by ultra-high-performance liquid chromatography and fluorescence detection (UHPLC-FL). Food Addit. Contam. Part A 2015, 32, 1352-1357. [CrossRef]

75. Urraca, J.L.; Huertas-Pérez, J.F.; Cazorla, G.A.; Gracia-Mora, J.; García-Campaña, A.M.; Moreno-Bondi, M.C. Development of magnetic molecularly imprinted polymers for selective extraction: Determination of citrinin in rice samples by liquid chromatography with UV diode array detection. Anal. Bioanal. Chem. 2016, 408, 3033-3042. [CrossRef] [PubMed]

76. Ferre, F.S. Worldwide occurrence of mycotoxins in rice. Food Control 2016, 62, 291-298. [CrossRef]

77. Aziz, N.H.; Mattar, Z.A.; Mahrous, S.R. Contamination of grains by mycotoxin-producing molds and mycotoxins and control by gamma irradiation. J. Food Saf. 2006, 26, 184-201. [CrossRef]

78. Zaied, C.; Zouaoui, N.; Bacha, H.; Abid, S. Natural occurrence of citrinin in Tunisian wheat grains. Food Control 2012, 28, 106-109. [CrossRef]

79. Limay-Rios, V.; Miller, J.D.; Schaafsma, A.W. Occurrence of Penicillium verrucosum, ochratoxin A, ochratoxin B and citrinin in on-farm stored winter wheat from the Canadian Great Lakes Region. PLoS ONE 2017, 12, e0181239. [CrossRef]

80. Dohnal, V.; Pavlikova, L.; Kuča, K. Rapid and sensitive method for citrinin determination using high-performance liquid chromatography with fluorescence detection. Anal. Lett. 2010, 43, 786-792. [CrossRef]

81. Richard, E.; Heutte, N.; Bouchart, V.; Garon, D. Evaluation of fungal contamination and mycotoxin production in maize silage Anim. Feed Sci. Technol. 2009, 148, 309-320. [CrossRef]

82. Richard, E.; Heutte, N.; Sage, L.; Pottier, D.; Bouchart, V.; Lebailly, P.; Garon, D. Toxigenic fungi and mycotoxins in mature corn silage. Food Chem. Toxicol. 2007, 45, 2420-2425. [CrossRef]

83. Garon, D.; Richard, E.; Sage, L.; Bouchart, V.; Pottier, D.; Lebailly, P. Mycoflora and multimycotoxin detection in corn silage: Experimental study. J. Agric. Food Chem. 2006, 54, 3479-3484. [CrossRef]

84. Kononenko, G.P.; Burkin, A.A. A survey on the occurrence of citrinin in feeds and their ingredients in Russia. Mycotoxin Res. 2008, 24, 3-6. [CrossRef]

85. Wang, M.L.; Lu, C.H.; Xu, Q.Y.; Song, S.Y.; Hu, Z.Y.; Zheng, Z.H. Four new citrinin derivatives from a marine-derived Penicillium sp. fungal strain. Molecules 2013, 18, 5723-5735. [CrossRef] [PubMed]

86. Meerpoel, C.; Vidal, A.; Andjelkovic, M.; De Boevre, M.; Tangni, E.K.; Huybrechts, B.; Devreese, M.; Croubels, S.; De Saeger, S. Dietary exposure assessment and risk characterization of citrinin and ochratoxin A in Belgium. Food Chem. Toxicol. 2021, 147, 111914. [CrossRef] [PubMed]

87. European Commission. Commission Regulation (EU) 2019/1901 of 7 November 2019 amending Regulation (EC) No 1881/2006 as regards maximum levels of citrinin in food supplements based on rice fermented with red yeast Monascus purpureus. Off. J. Eur. Union 2019, 62, 2-4.

88. European Commission. Commission Regulation (EU) No 212/2014 of 6 March 2014 amending Regulation (EC) No 1881/2006 as regards maximum levels of the contaminant citrinin in food supplements based on rice fermented with red yeast Monascus purpureus. EFSA J. 2014, 16, 3-4.

89. Chagas, G.M.; Klüppel, M.L.W.; de Paiva Campello, A.; de Freitas Buchi, D.; de Oliveira, M.B.M. Alterations induced by citrinin in cultured kidney cells. Cell Struct. Funct. 1994, 19, 103-108. [CrossRef]

90. Chagas, G.M.; Oliveira, M.B.M.; Campello, A.P.; Kluppel, M.L.W. Mechanism of citrinin-induced dysfunction of mitochondria. IV-Effect on Ca2+ transport. Cell Biochem. Funct. 1995, 13, 53-59. [CrossRef]

91. Yu, F.-Y.; Liao, Y.-C.; Chang, C.-H.; Liu, B.-H. Citrinin induces apoptosis in HL-60 cells via activation of the mitochondrial pathway. Toxicol. Lett. 2006, 161, 143-151. [CrossRef]

92. Iwahashi, H.; Kitagawa, E.; Suzuki, Y.; Ueda, Y.; Ishizawa, Y.-h.; Nobumasa, H.; Kuboki, Y.; Hosoda, H.; Iwahashi, Y. Evaluation of toxicity of the mycotoxin citrinin using yeast ORF DNA microarray and Oligo DNA microarray. BMC Genom. 2007, 8, 1-13. [CrossRef]

93. Vanacloig-Pedros, E.; Proft, M.; Pascual-Ahuir, A. Different toxicity mechanisms for citrinin and ochratoxin A revealed by transcriptomic analysis in yeast. Toxins 2016, 8, 273. [CrossRef]

94. Ribeiro, S.M.R.; Chagas, G.M.; Campello, A.P.; Kluppel, M.L.W. Mechanism of citrinin-induced dysfunction of mitochondria. V. Effect on the homeostasis of the reactive oxygen species. Cell Biochem. Funct. 1997, 15, 203-209. [CrossRef]

95. Chen, C.-C.; Chan, W.-H. Inhibition of citrinin-induced apoptotic biochemical signaling in human hepatoma G2 cells by resveratrol. Int. J. Mol. Sci. 2009, 10, 3338-3357. [CrossRef] [PubMed]

96. Máté, G.; Gazdag, Z.; Mike, N.; Papp, G.; Pócsi, I.; Pesti, M. Regulation of oxidative stress-induced cytotoxic processes of citrinin in the fission yeast Schizosaccharomyces pombe. Toxicon 2014, 90, 155-166. [CrossRef] [PubMed]

97. Kumar, R.; Dwivedi, P.D.; Dhawan, A.; Das, M.; Ansari, K.M. Citrinin-generated reactive oxygen species cause cell cycle arrest leading to apoptosis via the intrinsic mitochondrial pathway in mouse skin. Toxicol. Sci. 2011, 122, 557-566. [CrossRef] [PubMed]

98. Mike, N.; Papp, G.; Čertik, M.; Czibulya, Z.; Kunsági-Máté, S.; Ember, I.; Vágvölgyi, C.; Pesti, M.; Gazdag, Z. Regulation of cytotoxic, non-estrogenic, oxidative stress-induced processes of zearalenone in the fission yeast Schizosaccharomyces pombe. Toxicon 2013, 73, 130-143. [CrossRef] [PubMed]

99. Endo, A.; Kuroda, M. Citrinin, an inhibitor of cholesterol synthesis. J. Antibiot. 1976, 29, 841-843. [CrossRef] [PubMed]

100. Qingqing, H.; Linbo, Y.; Yunqian, G.; Shuqiang, L. Toxic effects of citrinin on the male reproductive system in mice. Exp. Toxicol. Pathol. 2012, 64, 465-469. [CrossRef] [PubMed] 
101. Xu, B.-j.; Jia, X.-q.; Gu, L.-j.; Sung, C.-k. Review on the qualitative and quantitative analysis of the mycotoxin citrinin. Food Control 2006, 17, 271-285. [CrossRef]

102. Vrabcheva, T.; Usleber, E.; Dietrich, R.; Märtlbauer, E. Co-occurrence of ochratoxin A and citrinin in cereals from Bulgarian villages with a history of Balkan endemic nephropathy. J. Agric. Food Chem. 2000, 48, 2483-2488. [CrossRef]

103. Bamias, G.; Boletis, J. Balkan nephropathy: Evolution of our knowledge. Am. J. Kidney Dis. 2008, 52, 606-616. [CrossRef]

104. López Sáncheza, P.; de Nijsa, M.; Spanjerb, M.; Pietric, A.; Bertuzzic, T.; Starski, A.; Postupolski, J.; Castellari, M.; Hortós, M. Generation of occurrence data on citrinin in food. EFSA Support. Publ. 2017, 14, 1177E. [CrossRef]

105. Lurá, M.C.; Fuentes, M.B.; Cabagna, M.; González, A.M.; Nepote, A.F.; Giugni, M.C.; Rico, M.; Latorre, M.G. Actividad de metabolitos de Penicillium citrinum sobre ratones Mus musculus. Rev. Iberoam. Micol. 2001, 18, 183-186. [PubMed]

106. Chan, W.-H. Effects of citrinin on maturation of mouse oocytes, fertilization, and fetal development in vitro and in vivo. Toxicol. Lett. 2008, 180, 28-32. [CrossRef] [PubMed]

107. Thacker, H.L.; Carlton, W.W.; Sansing, G.A. Citrinin mycotoxicosis in the guinea-pig. Food Cosmet. Toxicol. 1977, 15, 553-561. [CrossRef]

108. Jordan, W.H.; Carlton, W.W.; Sansing, G.A. Citrinin mycotoxicosis in the mouse. Food Cosmet. Toxicol. 1977, 15, 29-34. [CrossRef]

109. Hanika, C.; Carlton, W.W.; Tuite, J. Citrinin mycotoxicosis in the rabbit. Food Chem. Toxicol. 1983, 21, 487-493. [CrossRef]

110. Jordan, W.H.; Carlton, W.W.; Sansing, G.A. Citrinin mycotoxicosis in the rat. II. Clinicopathological observations. Food Cosmet. Toxicol. 1978, 16, 441-447. [CrossRef]

111. Hanika, C.; Carlton, W.W.; Boon, G.D.; Tuite, J. Citrinin mycotoxicosis in the rabbit: Clinicopathological alterations. Food Chem. Toxicol. 1984, 22, 999-1008. [CrossRef]

112. Kitabatake, N.; Trivedi, A.B.; Doi, E. Thermal decomposition and detoxification of citrinin under various moisture conditions J. Agric. Food Chem. 1991, 39, 2240-2244. [CrossRef]

113. Köppen, R.; Koch, M.; Siegel, D.; Merkel, S.; Maul, R.; Nehls, I. Determination of mycotoxins in foods: Current state of analytical methods and limitations. Appl. Microbiol. Biotechnol. 2010, 86, 1595-1612. [CrossRef]

114. Clark, B.R.; Capon, R.J.; Lacey, E.; Tennant, S.; Gill, J.H. Citrinin revisited: From monomers to dimers and beyond. Org. Biomol. Chem. 2006, 4, 1520-1528. [CrossRef]

115. Wang, Y.; Gao, H.; Xie, J.; Li, X.; Huang, Z. Effects of some flavonoids on the mycotoxin citrinin reduction by Monascus aurantiacus Li AS3. 4384 during liquid-state fermentation. AMB Express 2020, 10, 26. [CrossRef] [PubMed]

116. Ouyang, W.; Liu, X.; Wang, Y.; Huang, Z.; Li, X. Addition of genistein to the fermentation process reduces citrinin production by Monascus via changes at the transcription level. Food Chem. 2021, 343, 128410. [CrossRef] [PubMed]

117. Huang, Z.; Zhang, L.; Wang, Y.; Gao, H.; Li, X.; Huang, X.; Huang, T. Effects of rutin and its derivatives on citrinin production by Monascus aurantiacus Li AS3. 4384 in liquid fermentation using different types of media. Food Chem. 2019, 284, 205-212. [CrossRef] [PubMed]

118. Tokuşoğlu, Ö.; Alpas, H.; Bozoğlu, F. High hydrostatic pressure effects on mold flora, citrinin mycotoxin, hydroxytyrosol, oleuropein phenolics and antioxidant activity of black table olives. Innov. Food Sci. Emerg. Technol. 2010, 11, 250-258. [CrossRef]

119. Heperkan, D.; Dazkır, G.S.; Kansu, D.Z.; Karbancıglu Güler, F. Influence of temperature on citrinin accumulation by Penicillium citrinum and Peniccillium verrucosum in black table olives. Toxin Rev. 2009, 28, 180-186. [CrossRef]

120. Zhou, G.; Fu, L.; Li, X. Optimisation of ultrasound-assisted extraction conditions for maximal recovery of active monacolins and removal of toxic citrinin from red yeast rice by a full factorial design coupled with response surface methodology. Food Chem. 2015, 170, 186-192. [CrossRef]

121. Vaseghi, N.; Bayat, M.; Nosrati, A.C.; Ghorannevis, M.; Hashemi, S. Evaluation of the plasma jet effects on the Citrinin and Ochratoxin A producing species of the genus Penicillium. Bulg. Chem. Commun. 2018, 50, 383-392.

122. Price, M.S.; Conners, S.B.; Tachdjian, S.; Kelly, R.M.; Payne, G.A. Aflatoxin conducive and non-conducive growth conditions reveal new gene associations with aflatoxin production. Fungal Genet. Biol. 2005, 42, 506-518. [CrossRef]

123. Schmidt-Heydt, M.; Baxter, E.; Geisen, R.; Magan, N. Physiological relationship between food preservatives, environmental factors, ochratoxin and otapksPV gene expression by Penicillium verrucosum. Int. J. Food Microbiol. 2007, 119, 277-283. [CrossRef]

124. O'Callaghan, J.; Coghlan, A.; Abbas, A.; García-Estrada, C.; Martín, J.-F.; Dobson, A.D.W. Functional characterization of the polyketide synthase gene required for ochratoxin A biosynthesis in Penicillium verrucosum. Int. J. Food Microbiol. 2013, 161, 172-181. [CrossRef]

125. Yang, H.; Wang, X.; Li, Z.; Guo, Q.; Yang, M.; Chen, D.; Wang, C. The effect of blue light on the production of citrinin in Monascus purpureus M9 by regulating the mraox gene through lncRNA AOANCR. Toxins 2019, 11, 536. [CrossRef] [PubMed]

126. Wang, L.; Dai, Y.; Chen, W.; Shao, Y.; Chen, F. Effects of light intensity and color on the biomass, extracellular red pigment, and citrinin production of Monascus ruber. J. Agric. Food Chem. 2016, 64, 9506-9514. [CrossRef] [PubMed]

127. Atapattu, S.N.; Poole, C.F. Recent advances in analytical methods for the determination of citrinin in food matrices. J. Chromatogr. A 2020, 1627, 461399. [CrossRef]

128. Klingelhöfer, I.; Morlock, G.E. Lovastatin in lactone and hydroxy acid forms and citrinin in red yeast rice powders analyzed by HPTLC-UV/FLD. Anal. Bioanal. Chem. 2019, 411, 6655-6665. [CrossRef] [PubMed]

129. Liu, Y.; Wang, H.; Yao, S.; Zhu, P. Detection of trace amounts of citrinin in dried orange peel by using an optimized extraction method coupled with ultra-performance liquid chromatography-tandem mass spectrometry. Biomed. Chromatogr. 2018, 32 , e4237. [CrossRef] [PubMed] 
130. Atapattu, S.N.; Rosenfeld, J.M. Micro scale analytical derivatizations on solid phase. Trends Anal. Chem. 2019, 113, 351-356. [CrossRef]

131. Sajid, M.; Alhooshani, K. Dispersive liquid-liquid microextraction based binary extraction techniques prior to chromatographic analysis: A review. Trends Anal. Chem. 2018, 108, 167-182. [CrossRef]

132. Lhotská, I.; Kholová, A.; Machyňáková, A.; Hroboňová, K.; Solich, P.; Švec, F.; Šatínský, D. Preparation of citrinin-selective molecularly imprinted polymer and its use for on-line solid-phase extraction coupled to liquid chromatography. Anal. Bioanal. Chem. 2019, 411, 2395-2404. [CrossRef]

133. Ostry, V.; Malir, F.; Cumova, M.; Kyrova, V.; Toman, J.; Grosse, Y.; Pospichalova, M.; Ruprich, J. Investigation of patulin and citrinin in grape must and wine from grapes naturally contaminated by strains of Penicillium expansum. Food Chem. Toxicol. 2018, 118, 805-811. [CrossRef]

134. Guo, W.; Zhao, M.; Chen, Q.; Huang, L.; Mao, Y.; Xia, N.; Teng, J.; Wei, B. Citrinin produced using strains of Penicillium citrinum from Liupao tea. Food Biosci. 2019, 28, 183-191. [CrossRef]

135. Mandal, S.; Das, P. Ultrasensitive visual detection of mycotoxin citrinin with yellow-light emitting carbon dot and Congo red. Food Chem. 2020, 312, 126076. [CrossRef] [PubMed]

136. Wei, F.; Liu, X.; Liao, X.; Shi, L.; Zhang, S.; Lu, J.; Zhou, L.; Kong, W. Simultaneous determination of 19 mycotoxins in lotus seed using a multimycotoxin UFLC-MS/MS method. J. Pharm. Pharmacol. 2019, 71, 1172-1183. [CrossRef] [PubMed]

137. Li, Z.; Mao, Y.; Teng, J.; Xia, N.; Huang, L.; Wei, B.; Chen, Q. Evaluation of mycoflora and citrinin occurrence in Chinese liupao tea. J. Agric. Food Chem. 2020, 68, 12116-12123. [CrossRef] [PubMed]

138. Tangni, E.K.; Van Hove, F.; Huybrechts, B.; Masquelier, J.; Vandermeiren, K.; Van Hoeck, E. Citrinin determination in food and food supplements by LC-MS/MS: Development and use of reference materials in an international collaborative study. Toxins 2021, 13, 245. [CrossRef]

139. Twarużek, M.; Ałtyn, I.; Kosicki, R. Dietary supplements based on red yeast rice-A source of citrinin? Toxins 2021, 13 , 497. [CrossRef] [PubMed]

140. Twarużek, M.; Kosicki, R.; Kwiatkowska-Giżyńska, J.; Grajewski, J.; Ałtyn, I. Ochratoxin A and citrinin in green coffee and dietary supplements with green coffee extract. Toxicon 2020, 188, 172-177. [CrossRef] [PubMed]

141. Wu, L.; Li, G.; Xu, X.; Zhu, L.; Huang, R.; Chen, X. Application of nano-ELISA in food analysis: Recent advances and challenges. Trends Anal. Chem. 2019, 113, 140-156. [CrossRef]

142. Singh, G.; Velasquez, L.; Huet, A.-C.; Delahaut, P.; Gillard, N.; Koerner, T. Development of a sensitive polyclonal antibody-based competitive indirect ELISA for determination of citrinin in grain-based foods. Food Addit. Contam. Part A 2019, 36, 1567-1573. [CrossRef]

143. Huang, W.; Tu, Z.; Ning, Z.; He, Q.; Li, Y. Development of real-time immuno-PCR based on phage displayed an anti-idiotypic nanobody for quantitative determination of citrinin in Monascus. Toxins 2019, 11, 572. [CrossRef]

144. Zhang, W.; Duan, H.; Chen, R.; Ma, T.; Zeng, L.; Leng, Y.; Xiong, Y. Effect of different-sized gold nanoflowers on the detection performance of immunochromatographic assay for human chorionic gonadotropin detection. Talanta 2019, 194, 604-610. [CrossRef]

145. Atar, N.; Yola, M.L.; Eren, T. Sensitive determination of citrinin based on molecular imprinted electrochemical sensor. Appl. Surf. Sci. 2016, 362, 315-322. [CrossRef]

146. Xu, Y.; Ma, B.; Chen, E.; Yu, X.; Ye, Z.; Sun, C.; Zhang, M. Dual fluorescent immunochromatographic assay for simultaneous quantitative detection of citrinin and zearalenone in corn samples. Food Chem. 2021, 336, 127713. [CrossRef] [PubMed]

147. Yang, J.; Hu, Y.; Li, Y. Molecularly imprinted polymer-decorated signal on-off ratiometric electrochemical sensor for selective and robust dopamine detection. Biosens. Bioelectron. 2019, 135, 224-230. [CrossRef] [PubMed]

148. Hu, X.; Liu, Y.; Xia, Y.; Zhao, F.; Zeng, B. A novel ratiometric electrochemical sensor for the selective detection of citrinin based on molecularly imprinted poly (thionine) on ionic liquid decorated boron and nitrogen co-doped hierarchical porous carbon. Food Chem. 2021, 363, 130385. [CrossRef]

149. Shekhar, M.; Singh, N.; Dutta, R.; Kumar, S.; Mahajan, V. Comparative study of qualitative and quantitative methods to determine toxicity level of Aspergillus flavus isolates in maize. PLoS ONE 2017, 12, e0189760. [CrossRef]

150. Li, M.; Tong, Z.; Gao, X.; Zhang, L.; Li, S. Simultaneous detection of zearalenone, citrinin, and ochratoxin A in pepper by capillary zone electrophoresis. Food Addit. Contam. Part A 2020, 37, 1388-1398. [CrossRef]

151. Ranasinghe, M.; Quirino, J.P. Can we replace liquid chromatography with the greener capillary electrophoresis? Curr. Opin. Green Sustain. Chem. 2021, 31, 100515. [CrossRef]

152. Kuchenbuch, H.S.; Cramer, B.; Humpf, H.-U. Matrix binding of T-2 toxin: Structure elucidation of reaction products and indications on the fate of a relevant food-borne toxin during heating. Mycotoxin Res. 2019, 35, 261-270. [CrossRef]

153. Bryła, M.; Ksieniewicz-Woźniak, E.; Waśkiewicz, A.; Yoshinari, T.; Szymczyk, K.; Podolska, G.; Gwiazdowski, R.; Kubiak, K. Transformations of selected Fusarium toxins and their modified forms during malt loaf production. Toxins 2020, 12, 385. [CrossRef]

154. Gonçalves, C.; Mischke, C.; Stroka, J. Determination of deoxynivalenol and its major conjugates in cereals using an organic solvent-free extraction and IAC clean-up coupled in-line with HPLC-PCD-FLD. Food Addit. Contam. Part A 2020, 37, 1765-1776. [CrossRef]

155. Hou, Y.; Liu, J.; Shao, Y.; Peng, X.; Zhang, D.; Hu, L.; Chen, F.; Zhou, Y. Evaluation of the underestimation of citrinin content in Hongqu using hydrolysis treatments and UPLC-FLD. Food Control 2021, 130, 108245. [CrossRef] 
156. Vidal, A.; Marín, S.; Sanchis, V.; De Saeger, S.; De Boevre, M. Hydrolysers of modified mycotoxins in maize: $\alpha$-Amylase and cellulase induce an underestimation of the total aflatoxin content. Food Chem. 2018, 248, 86-92. [CrossRef]

157. Beloglazova, N.V.; De Boevre, M.; Goryacheva, I.Y.; Werbrouck, S.; Guo, Y.; De Saeger, S. Immunochemical approach for zearalenone-4-glucoside determination. Talanta 2013, 106, 422-430. [CrossRef] [PubMed]

158. Lu, Q.; Qin, J.-A.; Fu, Y.-W.; Luo, J.-Y.; Lu, J.-H.; Logrieco, A.F.; Yang, M.-H. Modified mycotoxins in foodstuffs, animal feed, and herbal medicine: A systematic review on global occurrence, transformation mechanism and analysis methods. Trends Anal. Chem. 2020, 133, 116088. [CrossRef]

159. Gupta, R.C.; Srivastava, A.; Lall, R. Ochratoxins and citrinin. In Veterinary Toxicology; Elsevier: Amsterdam, The Netherlands, 2018; pp. 1019-1027.

160. Wang, K.; Lin, Z.; Zhang, H.; Zhang, X.; Zheng, X.; Zhao, L.; Yang, Q.; Ahima, J.; Boateng, N.A.S. Investigating proteome and transcriptome response of Cryptococcus podzolicus $\mathrm{Y} 3$ to citrinin and the mechanisms involved in its degradation. Food Chem. 2019, 283, 345-352. [CrossRef] [PubMed]

161. Trivedi, A.B.; Doi, E.; Kitabatake, N. Toxic compounds formed on prolonged heating of citrinin under watery conditions. J. Food Sci. 1993, 58, 229-232. [CrossRef]

162. Hirota, M.; MENTA, A.; Yoneyama, K.; Kitabatake, N. A major decomposition product, citrinin H2, from citrinin on heating with moisture. Biosci. Biotechnol. Biochem. 2002, 66, 206-210. [CrossRef] [PubMed]

163. Lee, C.-L.; Chen, W.-P.; Wang, J.-J.; Pan, T.-M. A simple and rapid approach for removing citrinin while retaining monacolin K in red mold rice. J. Agric. Food Chem. 2007, 55, 11101-11108. [CrossRef] [PubMed]

164. Schmidt-Heydt, M.; Cramer, B.; Graf, I.; Lerch, S.; Humpf, H.-U.; Geisen, R. Wavelength-dependent degradation of ochratoxin and citrinin by light in vitro and in vivo and its implications on Penicillium. Toxins 2012, 4, 1535-1551. [CrossRef]

165. Wang, C.; Fu, Z.-L.; Chen, M.-H.; Ban, Z.; Wang, Y.-R.; Zhang, X.-W. Blue light effects on pigment and citrinin production in Monascus. In Proceedings of the 2009 3rd International Conference on Bioinformatics and Biomedical Engineering, Beijing, China, 11-13 June 2009; pp. 1-4.

166. Hajjaj, H.; Klaebe, A.; Goma, G.; Blanc, P.J.; Barbier, E.; François, J. Medium-chain fatty acids affect citrinin production in the filamentous fungus Monascus ruber. Appl. Environ. Microbiol. 2000, 66, 1120-1125. [CrossRef]

167. Priyadarshini, C.H.; Narasareddy, G.V. Amelioration of toxic effects of aflatoxin and citrinin by adsorbents in broilers. Indian Vet. J. 2010, 87, 23-25.

168. Panda, P.; Aiko, V.; Mehta, A. Effect of aqueous extracts of Mentha arvensis (mint) and Piper betle (betel) on growth and citrinin production from toxigenic Penicillium citrinum. J. Food Sci. Technol. 2015, 52, 3466-3474. [CrossRef] [PubMed]

169. Zhang, X.; Lin, Z.; Apaliya, M.T.; Gu, X.; Zheng, X.; Zhao, L.; Abdelhai, M.H.; Zhang, H.; Hu, W. The possible mechanisms involved in citrinin elimination by Cryptococcus podzolicus $\mathrm{Y} 3$ and the effects of extrinsic factors on the degradation of citrinin J. Microbiol. Biotechnol. 2017, 27, 2119-2128. [CrossRef] [PubMed]

170. Ahima, J.; Zhang, H.; Apaliya, M.T.; Zhang, X.; Yang, Q.; Zhao, L. The effect of Rhodotorula mucilaginosa on degradation of citrinin production by Penicillium digitatum and its toxin in vitro. J. Food Meas. Charact. 2019, 13, 2998-3004. [CrossRef]

171. Abd-Allah, E.F.; Ezzat, S.M. Natural occurrence of citrinin in rice grains and its biocontrol by Trichoderma hamatum. Phytoparasitica 2005, 33, 73-84. [CrossRef]

172. Chen, Y.-H.; Sheu, S.-C.; Mau, J.-L.; Hsieh, P.-C. Isolation and characterization of a strain of Klebsiella pneumoniae with citrinindegrading activity. World J. Microbiol. Biotechnol. 2011, 27, 487-493. [CrossRef]

173. Kanpiengjai, A.; Mahawan, R.; Lumyong, S.; Khanongnuch, C. A soil bacterium Rhizobium borbori and its potential for citrinindegrading application. Ann. Microbiol. 2016, 66, 807-816. [CrossRef]

174. Magro, M.; Moritz, D.E.; Bonaiuto, E.; Baratella, D.; Terzo, M.; Jakubec, P.; Malina, O.; Čépe, K.; De Aragao, G.M.F.; Zboril, R. Citrinin mycotoxin recognition and removal by naked magnetic nanoparticles. Food Chem. 2016, 203, 505-512. [CrossRef]

175. Savi, G.D.; Piacentini, K.C.; Scussel, V.M. Ozone treatment efficiency in Aspergillus and Penicillium growth inhibition and mycotoxin degradation of stored wheat grains (Triticum aestivum L.). J. Food Process. Preserv. 2015, 39, 940-948. [CrossRef]

176. He, S.; Liu, X.; Wang, Y.; Xie, J.; Gao, H.; Li, X.; Huang, Z. Metabolomics analysis based on UHPLC-Q-TOF-MS/MS reveals effects of genistein on reducing mycotoxin citrinin production by Monascus aurantiacus Li AS3 4384. LWT_Food Sci. Technol. 2020, 130, 109613. [CrossRef]

177. Kabak, B.; Dobson, A.D.; Var, I. Strategies to prevent mycotoxin contamination of food and animal feed: A review. Crit. Rev. Food Sci. Nutr. 2006, 46, 593-619. [CrossRef] [PubMed]

178. Kamle, M.; Mahato, D.K.; Devi, S.; Lee, K.E.; Kang, S.G.; Kumar, P. Fumonisins: Impact on agriculture, food, and human health and their management strategies. Toxins 2019, 11, 328. [CrossRef] [PubMed]

179. Kumar, P.; Mahato, D.K.; Sharma, B.; Borah, R.; Haque, S.; Mahmud, M.M.C.; Shah, A.K.; Rawal, D.; Bora, H.; Bui, S. Ochratoxins in food and feed: Occurrence and its impact on human health and management strategies. Toxicon 2020, 187, 151-162. [CrossRef] [PubMed]

180. Mahato, D.K.; Devi, S.; Pandhi, S.; Sharma, B.; Maurya, K.K.; Mishra, S.; Dhawan, K.; Selvakumar, R.; Kamle, M.; Mishra, A.K. Occurrence, impact on agriculture, human health, and management strategies of zearalenone in food and feed: A review. Toxins 2021, 13, 92. [CrossRef]

181. Mahato, D.K.; Kamle, M.; Sharma, B.; Pandhi, S.; Devi, S.; Dhawan, K.; Selvakumar, R.; Mishra, D.; Kumar, A.; Arora, S. Patulin in food: A mycotoxin concern for human health and its management strategies. Toxicon 2021, 198, 12-23. [CrossRef] 
182. Mahato, D.K.; Lee, K.E.; Kamle, M.; Devi, S.; Dewangan, K.N.; Kumar, P.; Kang, S.G. Aflatoxins in food and feed: An overview on prevalence, detection and control strategies. Front. Microbiol. 2019, 10, 2266. [CrossRef]

183. Schmidt-Heydt, M.; Stoll, D.; Geisen, R. Fungicides effectively used for growth inhibition of several fungi could induce mycotoxin biosynthesis in toxigenic species. Int. J. Food Microbiol. 2013, 166, 407-412. [CrossRef]

184. Liu, H.; Jiang, W.; Bi, Y.; Luo, Y. Postharvest BTH treatment induces resistance of peach (Prunus persica L. cv. Jiubao) fruit to infection by Penicillium expansum and enhances activity of fruit defense mechanisms. Postharvest Biol. Technol. 2005, 35, 263-269. [CrossRef]

185. Kinay, P.; Mansour, M.F.; Gabler, F.M.; Margosan, D.A.; Smilanick, J.L. Characterization of fungicide-resistant isolates of Penicillium digitatum collected in California. Crop Prot. 2007, 26, 647-656. [CrossRef]

186. Droby, S.; Wisniewski, M.; Macarisin, D.; Wilson, C. Twenty years of postharvest biocontrol research: Is it time for a new paradigm? Postharvest Biol. Technol. 2009, 52, 137-145. [CrossRef]

187. Nicosia, M.G.L.D.; Pangallo, S.; Raphael, G.; Romeo, F.V.; Strano, M.C.; Rapisarda, P.; Droby, S.; Schena, L. Control of postharvest fungal rots on citrus fruit and sweet cherries using a pomegranate peel extract. Postharvest Biol. Technol. 2016, 114, 54-61. [CrossRef]

188. Trabelsi, D.; Hamdane, A.M.; Said, M.B.; Abdrrabba, M. Chemical composition and antifungal activity of essential oils from flowers, leaves and peels of Tunisian Citrus aurantium against Penicillium digitatum and Penicillium italicum. J. Essent. Oil Bear. Plants 2016, 19, 1660-1674. [CrossRef]

189. Shao, X.; Cao, B.; Xu, F.; Xie, S.; Yu, D.; Wang, H. Effect of postharvest application of chitosan combined with clove oil against citrus green mold. Postharvest Biol. Technol. 2015, 99, 37-43. [CrossRef]

190. Jeong, R.-D.; Chu, E.-H.; Lee, G.W.; Cho, C.; Park, H.-J. Inhibitory effect of gamma irradiation and its application for control of postharvest green mold decay of Satsuma mandarins. Int. J. Food Microbiol. 2016, 234, 1-8. [CrossRef] [PubMed]

191. Lafuente, M.T.; Alférez, F. Effect of LED Blue Light on Penicillium digitatum and Penicillium italicum Strains. Photochem. Photobiol. 2015, 91, 1412-1421. [CrossRef] [PubMed]

192. Rojas-Argudo, C.; Palou, L.; Bermejo, A.; Cano, A.; del Río, M.A.; González-Mas, M.C. Effect of X-ray irradiation on nutritional and antifungal bioactive compounds of 'Clemenules' clementine mandarins. Postharvest Biol. Technol. 2012, 68, 47-53. [CrossRef]

193. Yamaga, I.; Kuniga, T.; Aoki, S.; Kato, M.; Kobayashi, Y. Effect of ultraviolet-B irradiation on disease development caused by Penicillium italicum in satsuma mandarin fruit. Hortic. J. 2015, 85, 86-91. [CrossRef]

194. Ben-Yehoshua, S. Effects of postharvest heat and UV applications on decay, chilling injury and resistance against pathogens of citrus and other fruits and vegetables. In International Conference: Postharvest Unlimited; ISHS: Leuven, Belgium, 2002; Volume 599, pp. 159-173.

195. Montesinos-Herrero, C.; Moscoso-Ramírez, P.A.; Palou, L. Evaluation of sodium benzoate and other food additives for the control of citrus postharvest green and blue molds. Postharvest Biol. Technol. 2016, 115, 72-80. [CrossRef]

196. Moscoso-Ramírez, P.A.; Montesinos-Herrero, C.; Palou, L. Control of citrus postharvest Penicillium molds with sodium ethylparaben. Crop Prot. 2013, 46, 44-51. [CrossRef]

197. Palou, L.; Usall, J.; Munoz, J.A.; Smilanick, J.L.; Vinas, I. Hot water, sodium carbonate, and sodium bicarbonate for the control of postharvest green and blue molds of clementine mandarins. Postharvest Biol. Technol. 2002, 24, 93-96. [CrossRef]

198. Youssef, K.; Ligorio, A.; Nigro, F.; Ippolito, A. Activity of salts incorporated in wax in controlling postharvest diseases of citrus fruit. Postharvest Biol. Technol. 2012, 65, 39-43. [CrossRef]

199. Luo, Y.; Zeng, K.; Ming, J. Control of blue and green mold decay of citrus fruit by Pichia membranefaciens and induction of defense responses. Sci. Hortic. 2012, 135, 120-127. [CrossRef]

200. Sharma, R.; Singh, D.; Singh, R. Biological control of postharvest diseases of fruits and vegetables by microbial antagonists: A review. Biol. Control 2009, 50, 205-221. [CrossRef]

201. Mandal, G.; Singh, D.; Sharma, R.R. Effect of hot water treatment and biocontrol agent (Debaryomyces hansenii) on shelf-life of peach. Indian J. Hortic. 2007, 64, 25-28.

202. Mossini, S.A.G.; Kemmelmeier, C. Inhibition of citrinin production in Penicillium citrinum cultures by neem [Azadirachta indica A. Juss (Meliaceae)]. Int. J. Mol. Sci. 2008, 9, 1676-1684. [CrossRef] [PubMed]

203. Mohajeri, F.A.; Misaghi, A.; Gheisari, H.; Basti, A.A.; Amiri, A.; Ghalebi, S.R.; Derakhshan, Z.; Tafti, R.D. The effect of Zataria multiflora Boiss Essential oil on the growth and citrinin production of Penicillium citrinum in culture media and cheese. Food Chem. Toxicol. 2018, 118, 691-694. [CrossRef]

204. Noori, N.; Yahyaraeyat, R.; Khosravi, A.; Atefi, P.; Akhondzadeh Basti, A.; Akrami, F.; Bahonar, A.; Misaghi, A. Effect of Zataria multiflora boiss. Essential oil on growth and citrinin production by Penicillium citrinum in culture media and mozzarella cheese. J. Food Saf. 2012, 32, 445-451. [CrossRef]

205. Vazquez, B.I.; Fente, C.; Franco, C.M.; Vazquez, M.J.; Cepeda, A. Inhibitory effects of eugenol and thymol on Penicillium citrinum strains in culture media and cheese. Int. J. Food Microbiol. 2001, 67, 157-163. [CrossRef] 